\title{
Communicating with Juries: Problems and Remedies
}

\author{
William W Schwarzer†
}

"There is no worse lie than a truth misun-
derstood by those who hear it."

William James

Two hundred years ago, Sir William Blackstone described trial by jury as the "grand bulwark of [our] liberties ...,", and "the most transcendent privilege which any subject can enjoy, or wish for." 2 That conception remains a cornerstone of the administration of justice in our country.

There is growing concern, however, that jury trials as they are now conducted caunot be depended on to produce informed and hence fair verdicts. ${ }^{3}$ Because the law has become more complex and trials more lengthy, the issues submitted to jurors are often technical and foreign to their experience. It has therefore become much more difficult for juries to return informed verdicts. As a result, the jury's capacity to serve as the repository of the people's sense of justice, reason, and fair play is being questioned. ${ }^{4}$

t United States District Judge, Northern District of California. A.B. 1948, University of Southern California; J.D. 1951, Harvard Law School. The assistance of Gail Ruetten Lopes, Jack Londen, Tony Tanke, Beth Tanke, Lia Matera, Cathleen Gilliland, and George Duesdieker is gratefully acknowledged.

1. 4 W. Blackstone, Commentaries 342 (Oxford 1769).

2. $3 \mathrm{id}$. at 379 (1768).

3. The roster of doubters includes Judges Jerome Frank, Learned Hand, Benjamin Cardozo, and most recently Chief Justice Warren Burger. See generally In re U.S. Financial Sec. Litigation, 609 F.2d 41 l, 429 n.66 (9th Cir. 1979), cert. denied, 446 U.S. 929 (1980); Note, The Case for Special Juries in Complex Civil Litigation, 89 YALE L.J. 1155 (1980). The opposing view was stated by the Ninth Circuit:

The assumption that attorneys cannot develop and present complex cases to a jury underestimates the abilities of the bar. . . . Whether a case is tried to a jury or to a judge, the task of the attorney remaims the same. [He] nust organize . . a complex mass of information into a form which is understandable to the uninitiated.

....

... [I]n view of the mandate of the Seventh Amendment, tinie might be better spent in searching for ways to improve rather than erode the jury systein.

609 F.2d at 427, 432. See also Jorde, The Seventh Amendment Right to Jury Trial of Antitrust Issues, 69 CALIF. L. REv. 1 (1981).

4. The federal courts disagree on whether the seventh amendment right to a jury trial extends to complex cases. The Ninth Circuit lias held that it does. In re U.S. Financial Sec. Litigation, 609 F.2d 411. The Third Circuit lias held that a jury trial nuay be denied on due process grounds where the court determines that the case is too complex for a jury to understand and 
This situation confronts the bench and the bar with the challenge of ensuring that juries return verdicts conforming to both the law and the evidence. This challenge imphicates all aspects of pretrial and trial management, but the critical pressure point probably is the instructing (charging) of the jury. Prevailing practices of instructing juries are often so archaic and unrealistic that even in relatively simple cases what the jurors hear is little more than legal inumbo juinbo to them. Responsibility for the shortcomings of present practices must be shared by lawyers, trial courts, and appellate courts-lawyers for submitting self-serving, excessively long and argumentative instructions, trial judges for adhering to archaic practices out of fear of being reversed, and appellate courts for elevating legal abstractions over juror understanding. This call for reform is therefore addressed to all three groups.

This Article discusses how the instruction of juries can and should be improved. Beginning with a brief review of the historical background of jury instructions and a discussion of pattern instructions, the Article goes on to explore the relevant findings of psycholinguistic studies. It then uses these findings to recommend improvements in the drafting and presentation of instructions. Finally, it suggests a more appropriate form of appellate court review in cases of alleged instructional error. ${ }^{5}$

\section{I \\ HISTORICAL BACKGROUND ${ }^{6}$}

Jury instructions as we know them today were not used until the nineteenth century. When courts began using juries to try lawsuits in twelfth-century England, the juries were composed of persons having direct knowledge of or access to the facts of the case. Jurors were sworn, read the charges, and then expected to arrive at a verdict, going without food and drink until they had done so. If they failed to agree, the judge would add inore jurors until there were twelve who agreed. ${ }^{7}$ The judge gave no instructions; although he could answer questions, the rule was that "the justices shall say nothing . . . for the instruction

decide rationally. In re Japanese Elec. Prod. Antitrust Litigation, 631 F.2d 1069 (3d Cir. 1980). See Note, The Right to a Jury Trial in Complex Civil Litigation, 92 HARv. L. Rev. 898 (1979).

5. This Article concentrates on the linguistic aspects of improving the quatity of jury trials. Although not discussed here, additional reforms inay also deserve consideration.

6. See generally $1 \mathrm{~W}$. HOLDSWORTH, A History OF ENGLISH LAW 312-50 (7th rev. ed. 1956); T. Plucknett, A Concise History of the Common Law 106-38 (5th ed. 1956); Readings on the History and System of the Common law 134-77 (3d ed. R. Pound \& T. Plucknett 1927) [hereinafter cited as READINGs].

7. Readings, supra note 6 , at 151 (quoting H. Bracton, De Legibus et ConsueTUDINIBUS ANGLIAE fol. 185 (1259, 1st primted ed. 1569)). 
of the jurors . . .".8

Judges had other methods of controlling the jury's verdict. If the judge doubted the jurors' truthfulness, he could interrogate thein individually. ${ }^{9}$ If the losing party made a showing of juror corruption or if a writ was issued by the chancellor or the chief justice of the eyre, a judicial commission responsible for reviewing verdicts, ${ }^{10}$ jurors could be subjected to attaint. Attaint entailed a review of the jury's verdict by a second jury of twenty-four. If the second jury found the verdict demonstrably false or "so obviously foolish that corruption might be presumed," "1 the members of the first jury could be miprisoned or stripped of their personal property. ${ }^{12}$ Judges used the threat of attaint to control verdicts. ${ }^{13}$

From about the fifteenth century, cases came to be decided on the testimony presented at trial rather than on the jurors' personal knowledge. ${ }^{14}$ Judges began to assist juries in clarifying issues and resolving inconsistencies. In theory, the judge offered direction only upon request, and a jury following such direction still risked attaint. In practice, however, jurors were strongly encouraged to request instructions by the increased threat of judges fining or imprisoning jurors for returning verdicts manifestly agaimst the evidence or for failing to follow the court's suggestions and threats. ${ }^{15}$

The practice of punishing jurors for returning verdicts against the . evidence ended with the decision in Bushel's Case in 1670. ${ }^{16}$ Members of the jury that had acquitted William Pemr of unlawful assembly in spite of the judge's attempt to starve them into a contrary decision had been fined and imprisoned for returning a verdict against the evidence. In granting a petition for a writ of habeas corpus, Chief Justice Vaughan held that the jury could not be punished for refusing to follow the court's direction. ${ }^{17}$ Attaint, although by then rarely used, was lield to be an adequate remedy to deal with verdicts contrary to the knowledge and true opmion of the jurors. Thus, a verdict had to be the prod-

8. Id.

9. Id. at 154.

10. For a discussion of the General Eyre, a periodic judicial convocation that performed a wide variety of other administrative tasks as well, see $1 \mathrm{~W}$. HoLDSwORTH, supra note 6, at 265-73.

11. Id. at 344 .

12. Id. at 341; T. PlUCKNETT, supra note 6, at 131.

13. See generally I W. HoLDSWORTH, supra note 6, at 337-47.

14. Id. at 317-19; T. PluCKNETt, supra note 6, at 129-30.

15. See $1 \mathrm{~W}$. HoldSWORTH, supra note 6, at 342-46; T. PLUCKNETT, supra note 6, at 133-34. See also Bushel's Case, Vaughan's Rep. 135, 148, 124 Eng. Rep. 1006, 1012 (1670).

16. Vaughan's Rep. 135, 124 Eug. Rep. 1006 (1670). See also I W. Holdsworth, supra note 6 , at 344-46.

17. Vaughan's Rep. at 143-51, 124 Eng. Rep. at 1010-14. 
uct of juror dishonesty, and not simply the product of the jury's independent judginent, before a juror could be punished.

The decision in Bushel's Case is considered to have establislied the supremacy of the English jury on questions of law as well as of fact, smce a general verdict resolved all issues in the case. The courts, lowever, reacted to that decision by turning to other inethods for controlling juries. It was no longer thought desirable to liave juries "substitute their vague and arbitrary discretion for the rules which the law lays down." ${ }^{18}$ If a jury returned an unsatisfactory verdict, the court could grant a new trial. By the middle of the eighteenth century, the practice of granting new trials liad becoine established, allowing the decisions of juries on issues of fact to be set aside for failure to follow the judge's instructions, or for returning a verdict against the evidence. ${ }^{19}$ Moreover, as the focus at trial shifted from the personal knowledge of the jurors to witness testimony and exhibits, questions of admissibility, competency, and privilege fathered the law of evidence. ${ }^{20}$ This indirectly allowed the judge to control the jury's deliberations by controlling the evidence introduced for its consideration.

The development of judicial control of juries in England-primarily through post-verdict remedies against jurors-is significant here for its contrast with the practice in the American colonies. One of the principal objections to the draft of the Constitution was its failure to guarantee jury trials, ${ }^{21}$ a defect remedied in the Bill of Rights. Devoted to egalitarian principles and distrustful of judges appointed by the King, the colonists jealously guarded the rights and powers of juries, witls judges and juries being more or less co-equals in the judicial process. ${ }^{22}$

In the early years of the Republic, the independence of the jury found strong support in state legislatures. Jurors were lauded as spokesinen for the common sense and shared ethics of the citizenry. Judges frequently gave no instructions at all, relying on the jurors to be "good judges of the common law of the land," 23 and assuring thein that the applicable rules of law "need[ed] no Explanation [since] your Good Sence \& understanding will Direct ye as to thein." 24 When instructions 1847)).

18. Readings, supra note 6, at 168 (quoting T. Sedgwick, Damages 201-02 (New York

19. T. PluCKNETT, supra note 6, at 135-36.

20. READINGS, supra note 6, at 169-77 (quoting $1 \mathrm{~J}$. WigMORE, EvidENCE $§ 8$ (1st ed. 1904)).

21. See The Federalist No. 83 (A. Hamilton).

22. Comment, The Changing Role of the Jury in the Nineteenth Century, 74 YALE L.J. 170, 173 (1964).

23. W. Nelson, AmERICANization of the CoMmon LAW 26 (1975) (quoting Letter from James Sullivan to Elbridge Gerry (Dec. 25, 1779) (collection of Mass. Hist. Soc'y, Boston)).

24. Id. (quoting Grand Jury Charge, 1 Cushing PAPERs (1759) (collection of Mass. Hist. Soc'y, Boston)). 
were given, the juries were not obligated to follow them. ${ }^{25}$ Even if jurors wanted to follow them they often could not; instructions were often contradictory, coming from a panel of judges witl eacl judge presenting his own interpretation of the law. ${ }^{26}$ The manner of giving instructions was informal; generally they were read to the jurors in the vernacular. $^{27}$

Jurors could decide questions of law as well as fact. As Chief Justice Jay explained in 1794:

[O]n questions of fact, it is the province of the jury, on questions of law, it is the province of the court to decide. But it must be observed that by the same law, which recognizes this reasonable distribution of jurisdiction, you have nevertheless a right to take upon yourselves to judge of both, and to determine the law as well as the fact in controversy. On this and on every other occasion, however, we have no doubt, you will pay that respect, which is due to the opinion of the court: For, as on the one hand, it is presumed that juries are the best judges of facts; it is, on the other hand, presumable that the court are the best judges of the law. But still both objects are lawfully, within your power of decision. ${ }^{28}$

Justice Story and other members of the judiciary made clear to jurors that although the jury had the power to decide questions of law, it liad no moral right to do so because the parties to an action were entitled to consistent application of the law. ${ }^{29}$ In contrast to the British system, however, the jury could not be pumshed, by attaint or otlerwise, for disregarding the judge's instruction. ${ }^{30}$

By the end of the nineteentl century, distrust of judges had been supplanted by the fear that jurors might ignore the positive law in favor of popular prejudices masquerading as "natural law." The growtlı of the Republic, with its proliferation of divergent interest groups, cast doubt on the existence of a shared ethic accessible to all jurors. Moreover, a stable economy required predictable application of property, contract, and debtor-creditor law if businessmen were to plan their future affairs. ${ }^{31}$ Accordingly, many states, through legislation or judicial control of the conduct of litigation, began to require that instructions

25. See, e.g., Georgia v. Brailsford, 3 U.S. (3 Dall.) 1, 4 (1794); 2 THE WORKS of JoHN ADAMs 254-55 (Boston 1850), quoted in Comment, supra note 22, at 172-73. See generally W. NeLSON, supra note 23, at 3, 18-20, 26, 28; Comment, The Jury Instruction Process-Apathy or Aggressive Reform?, 49 MARQ. L. REv. 137, 138 (1965).

26. W. NeLSON, supra note 23, at 3,26, 28.

27. L. Friedman, A History OF AMERICAN LAW 137 (1973); W. Nelson, supra note 23, at 26.

28. Georgia v. Brailsford, 3 U.S. (3 Dall.) 1, 4 (1794).

29. See Farley, Instructions to Juries-Their Role in the Judicial Process, 42 YALE L.J. 194, 203 (1932). 1804)).

30. Id. at 202-03 (quoting People v. Croswell, 3 Johns. Cas. ${ }^{* 337, ~}{ }^{*} 356$ (N.Y. Sup. Ct.

31. W. NeLSON, supra note 23, at 165. 
on every material point in issue be given by only one of the judges trying the case. ${ }^{32}$ Courts began using special and directed verdicts to restrict juries to determinations of fact. When juries returned verdicts contrary to the law, their failure to follow the court's instruction became grounds for a new trial. ${ }^{33}$ By 1895 , the Supreme Court had repudiated the right of federal juries to decide questions of law even in criminal cases, although the Court noted that such questions were sometimes addressed as a necessary consequence of returning a general verdict. $^{34}$

With the enactment of statutes requiring jury mstrnctions to be in writimg and barring trial judges from charging juries on the facts, ${ }^{35}$ appellate courts concomitantly gained a greater role in the instruction process. On review, appellate courts determined whether the judge's mstructions stated the law correctly, were applicable to the case, and were untamted by commentary on the facts. They determined whether, under the applicable law, an unprejudiced jury could have reached the verdict. This heightened supervisory role over the law presented to juries enabled the appellate courts to have substantial influence on jury trials.

As trial imstructions became subject to potentially demanding appellate review they became prolix, mconsistent, and excessively technical. Attorneys usually requested lengthy and argumentative instructions. Trial judges, uncertain of what might be required by the appellate courts, adopted lengthier and more complex mstructions in the hope that they would leave few grounds upon which to base a reversal. The process of trying cases thus became more burdensome for courts, counsel, and the parties. Reforn was badly needed and came through the development of pattern imstructions. ${ }^{36}$

Probably the first significant effort to develop pattern or standard instructions occurred in the Los Angeles Superior Court in the late 1930 's. ${ }^{37}$ A committee of judges drafted inodel imstructions based on the decisions of appellate courts and intended to be universally applicable to cases imvolving particular issues. Attorneys submitted requests

32. See, e.g., id. at 167-68.

33. See, e.g., id. at 168-69.

34. See Sparf v. United States, 156 U.S. 51, 80-82 (1895).

35. Chestnut, Instructions to the Jury, 3 F.R.D. 113, 114 (1944); Soper, The Charge to the Jury, 24 JUDICATURE 11 i (1940).

36. Corboy, Pattern Jury Instructions-Their Function and Effectiveness, 1964 A.B.A. SECTION of INS., NEGL. \& CoMPEN. L. 119, 119-20; Note, Standard Jury Instructions, 98 U. PA. L. REV. 223, 224 (1949).

37. An earlier effort by a group of Ohio judges was abandoned in 1927. Nieland, Assessing the Impact of Pattern Jury Instructions, 62 JudiCATURE 185, 186 (1978). See also R. NIELAND, PATTERn JuRy INSTRuctions: A CRITICAL LOOK AT A MODERN MOVEMENT To IMPROVe the JURY SYSTEM (1979). 
for instructions selected from among the standard forms and the court instructed the jury using those forms. ${ }^{38}$ These pattern instructions were published and caine into standard use throughout the California state court systen as California Jury Instructions-Civil (BAJI) and California Jury Instructions-Criminal (CALJIC).

Following the lead of California, nearly all states have adopted pattern instructions for civil or criminal cases or both, some making their use mandatory. ${ }^{39}$ In the federal system, the work of Judges Williain Mathes and Edward Devitt led to the publication of Federal Jury Practice and Instructions, a collection of instructions derived from appellate decisions which serves inuch the same purpose. ${ }^{40}$

II

A FOUNDATION FOR REFORM

\section{A. Pattern Instructions}

Pattern instructions were designed to serve four primcipal purposes: (1) Save the court and counsel time in preparing instructions; (2) eliminate argumentative instructions prepared by counsel; (3) improve accuracy and avoid error and thereby reduce the number of appeals and reversals; and (4) improve jury comprehension. ${ }^{41}$ Whether these desired results have been achieved, and at what cost, will be discussed in the following paragraphs.

First, the use of pattern instructions undoubtedly has resulted in time savings. It reduces the anount of time spent on legal research and drafting and on deciding which specific instructions will be given. ${ }^{42}$ Thus, in routine cases at least, the availability of standard instructions inay facilitate the work of court and counsel. But that availability may also lull the lawyers and the judge into a false sense of security, leading thein to omit the careful analysis of the facts and research of the law that nay be needed to determine which instructions are applicable to the particular case. ${ }^{43}$ Since the same analysis and research is essential to prepare for trial, any timesaving in this regard may be at the cost of adequate preparation.

Second, pattern instructions have not eliminated argumentative in-

38. See Palmer, Patterns for Jury Instructions, 29 CAN. B. REv. 256 (1951); Palmer, Standardized Jury Instructions Succeed, 23 JudiCATURE 177 (1940); Note, supra note 36, at 223-24.

39. See R. NielaND, supra note 37, at 13-14, 43-52; Neiland, supra note 37, at 187.

40. First published in 1965, it is now in its third edition. E. DevitT \& C. BLACKMAR, Federal JURY PRACtice AND Instructions (3d ed. 1977). Pattern instructions have also recently been published by the District Judges Association of the Fifth Circuit; instructions are being prepared by a committee of the Federal Judicial Center and by the Seventh Circuit.

41. Corboy, supra note 36, at 122-29; Note, supra note 36, at 223-25.

42. R. Niel_AND, supra note 37, at 15-16; Nieland, supra note 37, at 187-88.

43. See Note, supra note 36 , at 229-30. 
structions. The theory of pattern instructions is that their availability inakes judges less dependent on lawyers and hence better able to reject requests for arguinentative instructions. Nevertheless, arguinentative instructions continue to be submitted and frequently given. Most lawyers follow the practice of submitting adaptations of pattern instructions that stress the position they advocate. ${ }^{44}$ Some states have attempted to stop this practice by prohibiting the use of other than standard instructions if they adequately cover the case, but it will be a rare case in which counsel camiot nnake a reasonable argument in support of a modified standard instruction tailored to the particular case. ${ }^{45}$ Frequently, lawyers submit argumentative instructions under the guise of instructions on the theory of their case, or repetitive instructions giving undue einphasis to particular points.

Third, pattern instructions, being the product of scholarly research and extensive dehiberation, have, at least in theory, an edge in accuracy over those prepared under the pressure of hitigation. But accuracy and precision suffer in the atteinpt to draft a pattern instruction of sufficient generality to cover many cases. In any event, no evidence has been found indicating that their use reduces the number of appeals or reversals. A study of the impact of pattern instructions in Illinois concluded that they reduced neither the number of appeals nor the number of reversals for instructional error. ${ }^{46}$ Even if pattern instructions themselves are less likely to contain erroneous statements of law than tailormade instructions, the study showed that error on appeal is inore frequently based on the use or refusal of an instruction than on its wording. More important, the proportion of appeals based solely on instructional error is extrenely sunall and, in Illinois at least, remained substantially the saine even after adoption of mandatory pattern instructions. Finally, the statistics indicate that in those cases that did raise instructional error, the adoption of pattern instructions did not reduce the rate of reversal.

Fourth, whether pattern instructions improve jury comprehension depends, of course, on what they are compared to. Before pattern instructions were introduced, judges tended to take their instructions from stateinents of the law in appellate opmions. Pattern instructions provided, at a minimum, an opportunity to draft instructions that would improve juror understanding. But that consideration, unfortu-

44. R. Nieland, supra note 37, at 13-14; Cunningham, Instructing Juries, 32 CAL. ST. B.J. 127, 129-31 (1957).

45. Several states require that applicable pattern instructions be given unless the court determines them to be erroneous. See, e.g., ILl. Sup. CT. R. 25-1(a). California's Rules of Court merely recominend use of BAJI or CALIIC whenever they are applicable. CAL. R. CT. §5. See R. NiELAND, supra note 37, at 43-52; Nieland, supra note 37, at 185 .

46. R. NiELAND, supra note 37, at 16-22; Nieland, supra note 37, at 188-94. 
nately, was not a universal motivation for the draftsmen. The authors of the early edition of the California instructions, for example, stated: "[T]he one thing an instruction inust do above all else is to correctly state the law. This is true regardless of who is capable of understanding it."47

Not all states have taken a similar attitude. Efforts have been made by some to revise pattern instructions to ehininate words and concepts that are difficult for jurors to comprehend. ${ }^{48}$ In the absence of such efforts, however, there is nothing inherent in pattern instructions that promotes jury comprehension. On the contrary, the instructions generally used by the courts, whether true pattern instructions or sample instructions previously approved by appellate courts, abound with legal language and abstract concepts, both obstacles to juror coinprehension. ${ }^{49}$

Difficulties of comprehension are exacerbated by the frequently prolix instructions that result from the ready availability of pattern instructions. Lawyers seeking the benefit of repetition of what they consider helpful statements of law will often submit requests for redundant or unnecessary instructions, and judges, wanting to avoid reversal, tend to give all instructions requested so long as they are in approved form and apphicable to the case. In this way, availability breeds proliferation at the cost of jury coinprehension.

Pattern or standard instructions can serve a useful purpose as guides and checklists. ${ }^{50}$ Lawyers drafting instructions can refer to thein for a general statement of the legal elements of the case. Nevertheless, despite their convenience as a starting point, they are for the most part a poor vehicle for communicating with jurors. The benefits from their use, which are margimal at best, tend to be outweighed by the resulting obstacles to juror comprehension. The existence of those obstacles has

47. 1 CaliforNia JURY INSTRUCTIONS-CiviL (BAJI) at 44 (4th rev. ed. 1956). The authors added:

It has been bruited that our instructions are written in English that is "too good," "too highbrow"; that they ought to be written in the "language of the street." . . . No one, for us at least, ever has taken one of our instructions and translated it into "the language of Id.

the street" still correctly stating the law.

48. Forston, Sense and Non-Sense: Jury Trial Communication, 1975 B.Y.U. L. Rev. 601, 618-19.

49. For a discussion of some of the most commonly used California standard instructions for negligence cases, see Winslow, The Instruction Ritual, 13 Hastings L.J. 456, 460-67 (1962). See also R. NiELAND, supra note 37, at 39-40; Note, supra note 36, at 225-29.

50. See 1 E. DevitT \& C. BLACKMAR, supra note 40, 88.03 , at 247; Devitt, Ten Practical Suggestions About Federal Jury Instructions, 38 F.R.D. 75, 76 (1965); Forston, supra note 48, at 618-19. For a collection of different opinions concerning pattern instructions expressed by a number of federal judges, see Sinith, Effective Instructions to the Federal Jury in Civil Cases-A Consideration in Microcosm, 18 SYRACUSE L. Rev. 559, 576-79 (1967). 
been repeatedly demonstrated in psycholinguistic studies and experiments, discussed in the next section.

\section{B. Psycholinguistics}

Psycholinguistics apphies techniques of experimental psychology to achieve improvements in language processing and comprehension. Numerous psycholinguistic experiments have been performed with jurors or simulated jurors, primarily testing the variables of language, sentence structure, context, and volume. The results of those experiments serve as a logical starting point in the search for better ways of communicating with juries.

Not unexpectedly, those experiments confirm that obstacles to juror comprehension are created by the following structural "defects" in jury instructions: legal jargon and unfamiliar words, abstract terms and expressions, negative construction and negative word modifiers, complex sentences, passive forms, and lack of logical textual organization. ${ }^{51}$ The results of a recent study by Robert and Veda Charrow strongly suggest that jurors' comprehension difficulties are more likely to be linguistic than conceptual. Their study indicates that the greater the conceptual difficulty of an instruction, the greater will be the improvement in its comprehensibility following its transformation into simpler language. ${ }^{52}$ This suggests that conceptual complexity plays a secondary role in the comprehension of instructions; comprehensibility

51. Elwork, Sales \& Alfini, Juridic Decisions: In Ignorance of the Law or in Light of It?, 1 LAW \& HUMAN BEHAVIOR 163 (1977); see note 52 and accompanying text infra.

52. Charrow \& Charrow, Making Legal Language Understandable: A Psycholinguistic Study of Jury Instructions, 79 ColuM. L. REv. 1306, 1318-19, 1334 (1979). In their experiment, the Charrows compared juror comprehension of 52 commonly used BAJI instructions in their stan. dard form with comprehension of the instructions in a rewritten form. The greatest improvements in comprehension resulted from the following changes:

1. Eliminating nouns constructed from verbs and restoring the verb form (e.g., using "assume" rather than "make an assumption").

2. Relocating misplaced phrases (e.g., changing "A proximate cause of an mjury is a cause which, in natural and contmuous sequence, produces the imjury" to "A proximate cause of an mjury is something that triggers a natural chain of events that ultimately produces the imjury").

3. Eliminating technical vocabulary where possible (e.g., chauging "imputed" to "transferred").

4. Eliminating multiple negatives (e.g., changing "Innocent nisrecollection is not uncommon" to "People sometimes forget things and contradict themselves").

5. Eliminating or modifying the passive voice, particularly in subordmate clauses (e.g., changing "No emphasis thereon is imtended by me" to "That does not mean that I am trying to emphasize").

6. Simplifying sentences with subordinate clauses to conform to the logical progression of the ideas presented.

7. Restructuring the text by grouping ideas logically, indicating in advance the number of parallel ideas to be presented, and providing appropriate introductory and transitional statements.

Id. at $1336-40$. 
may be largely a function of how instructions are worded. ${ }^{53}$

Other studies have confirmed the need for avoiding legal jargon and terms not commonly found in jurors' vocabularies. In one study, ${ }^{54}$ jurors who had served in one or more trials in the District of Columbia Superior Court were given multiple-choice tests asking thein to select the correct ineaning of the legal terms frequently used in instructions. Over one-third of the jurors selected three or more incorrect definitions out of a total of ten. ${ }^{55}$ For example, nearly one-half of the jurors defined "preponderance of the evidence" to inean "a slow and careful pondering of the evidence" or "looking at the exhibits in the jury room" rather than "one party's evidence is stronger than the other's." More than one-fourth of the jurors failed to select equally obvious correct definitions for "burden of proof," "impeach," "admissible evidence," and "inference." 57 Another study showed that nearly half the jurors tested could not select the correct definition of "speculate."s8

Experimental studies also suggest that a significant eleinent of comprehension is prior knowledge of or exposure to a situation. Listeners do not simply interpret and store information; they create a semantic product. This product is an image or understanding derived from the received information and prior knowledge. Providing the listener with a context in which to receive and process the new information aids coinprehension and recall. ${ }^{59}$ These studies indicate that comprehension and recall improve markedly when listeners are given an introduction or are first shown a picture depicting the context of the abstract statement read to thein. ${ }^{60}$ The results provide a powerful argument agamst the use of abstract statements of legal primciples and for the use of instructions phrased as concrete statements of the questions to be decided, incorporating the evidentiary context of persons, places, things, and events disclosed at trial. ${ }^{61}$

Comprehension and recall are also affected by limitations on the ability to assimilate the inaterial presented. During a verbal presenta-

\footnotetext{
53. Id. at 1334 .

54. O'Reilly, Why Some Juries Fail, 41 D.C.B.J. 69 (1974).

55. Id. at 73 .

56. Id. at 74 .

57. Id.

58. Forston, supra note 48, at 615.

59. See S. Hayakawa, Language in Thought and Action 57 (2d ed. 1949): We learn the meanings of practically all our words (which are, it will be remembered, merely complicated noises), not from dictionaries, but from hearing these uoises in life and learning to associate certain noises with certain situations . . by being aware, in short, of contexts.

60. Bransford \& Johnson, Contextual Prerequisites for Understanding: Some Investigations of Comprehension and Recall, 11 J. Verbal LEARNING \& VeRBAL BeHAVIOR 717 (1972).

61. See id. See also United States v. Holley, 502 F.2d 273, 276 (4th Cir. 1974); United States v. Barber, 442 F.2d 517, 527-28 (3d Cir.), cert. denied, 404 U.S. 846 (1971).
} 
tion of a series of concepts and items of information, a listener normally will lack the time needed to complete processing, imterpretimg, and storing the material. Listeners must therefore reduce the ainount of information received by being selective. They may overgeneralize by excluding information thought to be nonessential. Or they may draw inferences based less on the text than on prior knowledge. As a result, a listener exposed to a text that exceeds his absorptive capacity may acquire ideas different from those that the speaker intended to express. ${ }^{62}$

Unfortunately, jury instructions, especially pattern or standard instructions derived largely from appellate opimions, generally have not mcorporated this knowledge. It is therefore not surprising that other experiments have shown that a large proportion of jurors do not understand the instructions they receive and do not follow them.

In one study, 114 experienced jurors were read civil and criminal instructions and appropriate factual background imformation. ${ }^{63}$ The instructions were only twenty minutes long and involved no complex issues. The test was administered immediately after the reading of the instructions. Nevertheless, the mean of the imdividual scores was only forty-six percent correct with civil instructions and fifty-three percent correct with criminal instructions. Eighty-five pcrcent of the jurors missed at least one question on evidence, thirty-seven percent missed two out of three questions on evidence, and eighty-six percent could not choose the correct response relating to proof of guilt.

In another study, a comprehension test consisting of forty inultiple-choice and true-false questions was administered to 116 prospective Florida jurors immediately after they were read the state's pattern criminal instructions applicable to the case. The following results were obtained: Forty-three percent rejected or doubted the propriety of circumstantial evidence; twenty-three percent believed that when faced with two equally reasonable constructions, one being consistent with guilt, the defendant should be convicted; only fifty percent understood that the state had the burden of proving the defendant's guilt beyond a reasonable doubt; and two percent believed that the burden of proving innocence rested on the defendant. ${ }^{64}$

The results of these studies and experiments, disturbing as they are, should not surprise anyone who lias observed the jury systein in

62. See Fredericksen, Acquisition of Semantic Information from Discourse: Effects of Repeated Exposure, 14 J. Verbal Learning \& Verbal Behavior 158 (1975).

63. Forsten, supra note 48, at 613-15. See also Forsten, Judge's Instructions: A Quantitative Analysis of Jurors' Listening Comprehension, 18 TODAY's SPEECH, Fall 1970, at 34.

64. Strawn \& Buchanan, Jury Confusion: A Threat 10 Justice, 59 JudicAtuRE 478, 481-82 (1976). See also Erlanger, Jury Research in America, Its Past and Future, 4 LAw \& Soc'y Rev. 345, 348-49 (1970); Head, Confessions of a Juror, 44 F.R.D. 330, 336 (1968). 
operation. Even if one could argue about the particulars of their interpretation, these results would still present a compelling case for prompt and enlightened action to improve the methods of instructing juries. The following sections of this Article suggest various improvements that courts and counsel should consider when communicating with juries.

\section{III \\ More EfFective COMmunication with JuRIES}

\section{A. Language and Construction}

"We lawyers," notes Richard Wydick, "cannot write plain Enghish. We use eight words to say what could be said in two. We use old, arcane phrases to express commonplace ideas. Seeking to be precise, we become redundant. Seeking to be cautious, we become verbose." 65 The same is true of judges whose English often carries the additional burden of pomposity.

Unfortunately, legal usage, hallowed by traditions tracing back to the common law, is not easily changed. Although there is encouragement to cliange, the legal profession steadfastly adheres to the established ways. American lawyers and judges are not easily convinced of the truth of John Keunetlı Galbraitll's statement that "there are no important propositions that cannot be stated im plain language." 66 As a practical defense for their reluctance to change, they can always point to the experience of Judge Robert Winslow, an early advocate of plainEnglish jury imstructions, whose simplified neghigence instruction was held to be reversible error. ${ }^{67}$

The problem is compounded by the difficulty of writing good English, even if one sets out to do so. It is easier and takes less time to write wordy and complicated prose than clear and simple English. Poor

65. Wydick, Plain English for Lawyers, 66 CALIF. L. REv. 727 (1978).

66. Galbraith, Writing, Typing \& Economics, ATLANTIC, Mar. 1978, at 102, 105, quoted in Wydick, supro note 65 , at 756 .

67. Godwin v. LaTurco, 272 Cal. App. 2d 475, 77 Cal. Rptr. 305 (1st Dist. 1969). Holding that the trial court had erred by failing to give a proximate cause instruction, the court observed: "The trial judge understandably believed that BAII instruction 104 on proximate cause, standing alone, is loaded with naked abstractious and is not always a ready tool to assist a lay jury. . . . Nevertheless, the omission of such an instruction is an elevator giving ready access to the justices upstairs." Id. at 479, 77 Cal. Rptr. at 307 (citation omitted). Cf. Laub, Trial and Submission of $a$ Case from a Judge's Standpoint, 34 TEMP. L.Q. 1, 10 (1960) (Judge Laub, criticizing the trend toward "colorless and prosaic" instructions, said:

Ours is a respectable profession, quasi-scientific in nature, and comprised of learned men, and to require thein to indulge the language of the streets in preference to a more hiterary style is to debase an honorable calling which, in this skeptical age, could use a little increase of stature rather than the contrary.)

See also Winslow, supra note 49, at 471-72; text accompanying note 47 supra. 
writing habits are not the sole reason for this difficulty; clear writing also requires clear thinking. To shed unnecessary words, one must decide which are unnecessary. To write orderly prose, one must organize one's ideas. To avoid cliches, one must make the effort to recognize and excise them.

While this Article is not intended to teach good writing, the following guidelines are recommended for drafting jury imstructions:

1. Omit unnecessary words. Examine each word and ask whether it pulls its weight in the sentence. Examine each sentence and ask what it adds and whether the thought can be stated more succinctly.

2. Use simple, concrete words. Whenever possible substitute commonplace and concrete words and phrases for abstractions, chiches, technical terms, and legalese expressions.

3. Use short sentences.

4. Use the active voice.

5. Avoid negative forms.

6. Present the subject matter in an orderly, logical sequence. Each sentence, paragraph, and section should be organized to facilitate comprehension. Introductory statements should tell the histener what to expect and transitional statements should guide him. Parallel ideas should be unnounced and presented as such. ${ }^{68}$

\section{B. Integrating Facts and Law}

The psycholinguistic studies previously discussed tell us that a verbal message is better understood and retained if the listener can fit it into a semantic context. An abstract general statement about negligence, for example, will be less meaningful to the listener than one statimg the same idea in the specific context of the facts presented at trial. By the time the final instructions are given, the jury will have acquired a context from the evidence. Instructions should therefore state the legal principles or issues in language incorporating that evidence.

This does not mean that the judge should necessarily summarize the evidence or give more than very brief instructions on the parties' factual contentions. ${ }^{69}$ It does mean that imstructions should incorporate

68. See W. Strunk \& E. White, The Elements of StYle (3d ed. 1979); Charrow \& Charrow, supra note 52; Wydick, supra note 65.

69. In the federal courts, the trial judge may explain and comment on the evidence whenever that is thought necessary to assist the jury in arriving at a just verdict. That authority, however, is not without limits; when it is used, it must be made clear that the jury is to determme all matters of fact and that the judge's comments must not prejudice their judgment. Quercia v. Umited States, 289 U.S. 466,469 (1933).

Some commentators have urged greater use by federal judges of their power to summarize the evidence in order to aid the jury's deliberation. Devitt, supra note 50; Soper, supra note 35. 
the relevant persons, transactions, conduct, and events and state concretely the questions the jury is to decide. ${ }^{70}$

Traditionally, instructions consist of lengthy statements of abstract legal propositions accompanied by definitions of the legal terms used. An example is the standard conspiracy instruction found in Devitt and Blackmar, partially reprinted below. ${ }^{71}$ Given our knowledge of human intelligence, how much of that instruction (which undoubtedly states the law with impeccable accuracy) can we expect normal jurors to com-

But there are good reasons for not doing so. It is time consuming. It is difficult, if not impossible, to summarize evidence accurately and fairly, which creates an additional source of reversible error. And the jury may be confused if their recollection of the evidence differs substantially from the judge's. See United States v. Cohen, 145 F.2d 82, 92-93 (2d Cir. 1942). For a survey of state law on the point, see Rossinan, The Judge-Jury Relationship in the State Courts, 3 F.R.D. 98, 103 (1944).

70. See, e.g., the development of process instructions that state the component issues the jury must decide in the order they are to be decided. Taylor, Buchanan, Pryor \& Strawn, Avoiding the Legal Tower of Babel, 19 JuDGE's J., Summer 1980, at 10.

71. A conspiracy is a counbination of two or more persons, by concerted action, to accomphish some unlawful purpose, or to accomplish some lawful purpose by unlawful means. So, a conspiracy is a kind of "partnership in criminal purposes," in which eacl meinber becomes the agent of every other neunber. The gist of the offense, is a combimation or agreement to disobey, or to disregard, the law.

Mere similarity of conduct anong various persons, and the fact they may lave associated with each other, and may have assembled together and discussed common aims and interests, does not necessarily establish proof of the existence of a conspiracy.

However, the evidence in the case need not slow that the members entered into any express or formal agreement, or that they directly, by words spoken or in writing, stated between themselves what their object or purpose was to be, or the details thereof, or the means by which the object or purpose was to be accoinplished. What the evidence in the case unust show beyond a reasonable doubt, in order to establish proof that a conspiracy existed, is that the meinbers in some way or inanner, or through soine contrivance, positively or tacitly came to a mutual understanding to try to accoinplish a common and unlawful plan.

The evidence in the case need not estabhish that all the means or methods set forth in the indictment were agreed upon to carry out the alleged conspiracy; nor that all ineans or methods, which were agreed upon, were actually used or put into operation; nor that all of the persons charged to have been members of the alleged conspiracy were such. What the evidence in the case must establisl beyond a reasonable doubt is that the alleged conspiracy was knowingly formed, and that one or more of the ineans or methods described in the indictment were agreed upon to be used, in an effort to effect or accomphish some object or purpose of the conspiracy, as charged in the indictment; and that two or more persons, including one or more of the accused, were knowingly inembers of the conspiracy, as charged in the indictment.

One may become a member of a conspiracy without full knowledge of all.the details of the conspiracy. On the other hand, a person who lias no knowledge of a conspiracy, but happens to act in a way which furthers some object or purpose of the conspiracy, does not thereby become a conspirator.

Before the jury inay find that a defendant, or any other person, has becoine a member of a conspiracy, the evidence in the case must show beyond a reasonable doubt that the conspiracy was knowingly formed, and that the defendant, or other person who is claimed to have been a nember, willfully participated in the unlawful plan, with the intent to advance or further some object or purpose of the conspiracy.

To act or participate willfully ineans to act or participate voluntarily and intentionally, and with specific intent to do something the law forbids, or with specific intent to fail to do something the law requires to be done; that is to say, to act or participate with the bad purpose either to disobey or to disregard the law. So, if a defendant, or any other person, with understanding of the unlawful character of a plan, knowingly encour- 
prehend, retain, and intelligently apply? A correct and fair verdict is more likely to be obtained by a short and simple instruction that the jury can understand, reinember, and apply. The following instruction, tailored to the facts of a specific case, is illustrative:

In this case, the defendant is accused of having been a inember of a conspiracy to import cocaine. A conspiracy is a kind of criminal partnership: an agreement or combination of two or more people to do something unlawful. The agreement or combination is the crime; it does not matter whether it was successful or not.

It is not necessary that the members of a conspiracy made a formal agreement or that they agreed on every detail of the conspiracy. On the other hand, it is not enough if you merely find that they associated together, discussed inatters of common interest, acted in similar ways or helped one another. You must find beyond a reasonable doubt a jomt plan to import cocaine.

Such an instruction should, of course, be supplemented or modified to fit a particular case. ${ }^{72}$ But instructions can and should oimt broad abstractions derived from the generalizations of appellate courts intended to state rules applicable to many cases; since the jury has only one case to decide, the instructions sliould be honed down to what is essential for that case. ${ }^{73}$

If their virtues are so obvious, why are such instructions not given? Aside from judges' and lawyers' reluctance to stray froin the beaten path-in part out of fear of reversal ${ }^{74}$ - nore time and effort are required to draft simple and comprehensible instructions than to copy pattern or standard instructions. The latter may provide a helpful

ages, advises or assists, for the purpose of furthering the undertaking or scheme, he thereby becomes a willful participant-a conspirator.

One who willfully joins an existing conspiracy is charged with the same responsibility as if he had been one of the originators or instigators of the conspiracy.

In determining whether a conspiracy existed, the jury should consider the actions and declarations of all of the alleged participants. However, in determining whethcr a particular defendant was a member of the conspiracy, if any, the jury should consider only his acts and statements. He cannot be bound by the acts or declarations of other participants until it is established that a conspiracy existed, and that he was one of its members.

E. Devitr \& C. BlackmaR, supra note $40, \S \S 27.04-.05$, at $4-5,7-8$.

72. The Appendix, infra, illustrates how the simplified instruction was used in one case. The same technique is applicable to other issues. Instructions on negligence and proximate cause, on violations of the securities and antitrust laws, and on virtually every issue submitted to the jury can benefit from simplification and contextual integration.

73. See 1959 Institute for California Judges-Panel Discussion Part III: Instructing the Jury, 47 CALIF. L. Rev. 888, 895, 900 (I959) (comments of Judge William Sweigert and Professor David Louisell) [hereinafter cited as Panel Discussion]. It would, of course, not be sufficient simply to ask the jury to decide specific factual questions. Morris v. United States, 156 F.2d 525, 528 (9th Cir. 1946). See generally Winslow, supra note 49.

74. But see United States v. Aloi, 511 F.2d 585, 594-95 (2d Cir.), cert. denied, 423 U.S. 1015 (1975) (upholding a brief, plain language conspiracy instruction). 
checklist or frame of reference, ${ }^{75}$ but the evidence convincingly deinonstrates that the need, especially in complex cases, for instructions drafted in conformity with the principles here discussed justifies their cost.

\section{Limiting the Volume of Instructions}

As was inentioned above, psycholinguistic studies show that human capacity to process, store, and recall semantic infornation is limited; exceeding that capacity produces confusion and error. Yet instructions to juries frequently ignore this obvious fact. Their length is generally governed by the number of proposed instructions submitted by the attorneys, not by the judge's determination of what is essential.

Tailoring the length of instructions to human absorptive capacity, while desirable, is not always feasible; the demands of the particular case must control. But no instruction should be given without first being closely examined to determine whether it is really necessary. Few cases, if properly prepared, should require instructions taking inore than twenty to thirty minutes to read. ${ }^{76}$

What instructions are necessary will depend on the substantive and procedural rules governing the facts of the particular case. The reported decisions provide only limited guidance; the courts generally have not been concerned with simplifying instructions and trimming excess verbiage, and the decisions theinselves turn on the facts of the cases. Nevertheless, a review of federal criminal cases addressing coinmon subjects for instruction is useful im suggesting which instructions are mandatory and which may be omitted, even if no universal rules can be distilled.

75. See 1 E. DevitT \& C. BLACKMAR, supra note 40 , § 8.03, at 247 ; text accompanying note 50 supra.

76. In United States v. Cohen, 145 F.2d 82, 93 (2d Cir. 1942), a case imvolving a seven month trial of 27 defendants charged with 30 counts of mail fraud and conspiracy, Judge Learned Hand, in upholding the trial judge's rejection of defendants' 366 requests for mstructions, said:

We have agam and again discountenanced requests in such numbers. We do not of course mean that the parties to any trial ... should not be allowed to suggest to the judge what they believe to be their rights, privileges, or immunities. . . . But [here] if he had given the instructions in ipsissimis verbis, he would have nierely added to whatever was that confusion against whieh the accused so vociferously protest. Whatever enlightenment a jury gets, ordinarily it gets from the colloquial charge, and from any later colloquial additions to it. It is exceedingly doubtful whether a succession of abstract propositions of law, pronounced staccato, has any effect but to give them a dazed sense of being called upon to apply some esoteric mental processes, beyond the scope of their daily experience which should be their reliance. . . . [I]n many jurisdictions sucls requests are taken more seriously ... . ; we can only say in answer, that to do so appears ... to be part of that attitude towards the institution, which on the one hand affeets to suppose that laymen are capable of making effective use of any number of abstract legal propositions, couehed in unfamiliar terms, while on the other laand, they are subject to whims, caprices and passions which make the slightest alien intrusion a ground for upsetting all that they may have done. We do not share that attitude. 
At the outset, one must consider the different consequences that follow depending on whether counsel has actually requested an imstruction on a particular poimt. In the absence of plain error, the giving or the failure to give an instruction may not be raised for the first time after the verdict. ${ }^{77} \mathrm{~A}$ criminal conviction will be reversed for failure to give an unrequested instruction only where necessary to prevent a miscarriage of justice or to preserve the integrity of the judicial process. ${ }^{78}$ The corollary rule is that the rejection of a request for a correct and applicable imstruction will be reversed on appeal if found to be prejudicial. However, a requested instruction need not be given in the form submitted by counsel. The court las wide latitude in framing instructions so long as the substance of the request is satisfied. ${ }^{79}$

Case law suggests that, depending on the context, instructions on the following subjects may be mandatory regardless of whetler they are requested:

1. Each essential element of the offense charged that is in issue and particularly the requisite intent; ${ }^{80}$

2. The burden of proof and probably the presumption of innocence; ${ }^{81}$

77. Federal Rules of Criminal Procedure 30 states in relevant part, "No party may assign as error any portion of the charge or omission therefrom unless he objects thereto before the jury retires . . . FED. R. CRIM. P. 52(b) states, "Plain errors or defects affecting substantial rights may be noticed although they were not brought to the attention of the court." Federal Rules of Civil Procedure states, "No party may assign as error the giving or the failure to give an instruction unless he objects thereto before the jury retires . . . ."

Instructional error not raised in the trial court will rarely justify reversal of a conviction. Henderson v. Kibbe, 431 U.S. 145, 154 (1977); United States v. Ghickman, 604 F.2d 625, 631-32 (9th Cir. 1979), cert. denied, 444 U.S. 1080 (1980). But where a timely and proper request or objection has been made, an instructional error is grounds for reversal unless found to be harmless. United States v. Strand, 574 F.2d 993, 995 n.1 (9th Cir. 1978).

78. United States v. Mills, 597 F.2d 693, 700 (9th Cir. 1979); United States v. Segna, 555 F.2d 226, 231 (9th Cir. 1977).

79. See United States v. James, 576 F.2d 223, 226 (9th Cir. 1978). See also Washington State Bowling Proprietors Ass'n v. Pacific Lanes, Inc., 356 F.2d 371, 376-77 (9th Cir. 1966) (trial judge, while under no obligation to give a faulty instruction, may still be obligated to mstruct on a material issue). The court's instructions may not be judged in isolation but are viewed in the context of the overall charge. Henderson v. Kibbe, 431 U.S. 145, 152-53 \& n.10 (1977); United States v. Park, 421 U.S. 658, 674 (1975).

80. United States v. King, 587 F.2d 956, 965-66 (9th Cir. 1978); United States v. DeMarco, 488 F.2d 828, 832 (2d Cir. 1973). But where the element is undisputed, United States v. King, 587 F.2d at 965-66; Olar v. United States, 391 F.2d 773, 775 (9th Cir. 1968), hypothetical, United States v. Tri-State Motor Transit Co., 550 F.2d 494, 495 (9th Cir. 1977), involves a term that the jury should already understand, United States v. Smith, 442 F.2d 448, 449 (9th Cir. 1971) ("knowledge"); Vuckson v. United States, 354 F.2d 918, 922 (9th Cir.), cert. denied, 384 U.S. 991 (1966) ("perjury"), or works to the advantage of the defendant in being omitted, Brothers v. United States, 328 F.2d 151, 157 (9th Cir.), cert. denied, 377 U.S. 1001 (1964), failure to imstruct will not result in plain error. As to the need to instruct on requisite intent, see United States $v$. Bolden, 514 F.2d 1301, 1309 (D.C. Cir. 1975); United States v. Bryant, 461 F.2d 912, 920-21 (6th Cir. 1972); United States v. Porter, 431 F.2d 7, 9-10 (9th Cir.), cert. denied, 400 U.S. 960 (1970).

81. Taylor v. Kentucky, 436 U.S. 478, 486 n.13 (1978). See also In re Winship, 397 U.S. 358 , 362-64 (1970). Whether the omission of an instruction regarding the presumption of innocence 
3. The need for caution in accepting uncorroborated testimony of an accomplice or an informer, at least where it may be suspect; ${ }^{82}$

4. In a multiple conspiracy case, the restriction against using evidence from one conspiracy to prove another, ${ }^{83}$ and

5. The limitation on the use of a confession as evidence when voluntariness is in question. ${ }^{84}$

amounts to constitutional error depends on the facts of the case, the circumstances of the trial, and the balance of the instructions given. Kentucky v. Whorton, 441 U.S. 786, 789 (1979) (per curiam); Taylor v. Kentucky, 436 U.S. at 486 (citing Estelle v. Williams, 425 U.S. 501,503 (1976)); see, e.g., United States v. Fernandez, 496 F.2d 1294, 1298-99 (5th Cir. 1974).

82. United States v. Martin, 489 F.2d 674, 677 n.3 (9th Cir. 1973), cert. denied, 417 U.S. 948 (1974); see Caldwell v. United States, 405 F.2d 613, 615 (9th Cir.), cert. denied, 394 U.S. 1004 (1969). General instrnctions on the credibility of witnesses, United States v. McSweaney, 507 F.2d 298, 301 (9th Cir. 1974); United States v. Ketola, 478 F.2d 64, 66 (9th Cir.), cert. denied, 414 U.S. 847 (1973), and argument by counsel, United States v. Ketola, 478 F.2d at 66, have been leld to be sufficient substitutes for more specific cautionary instructions. A cautionary instruction need not be given sua sponte if accomplice testimony is corroborated. United States v. Busby, 484 F.2d 994, 997 (9th Cir. 1973), cert. denied, 415 U.S. 980 (1974).

Testimony by paid informers and immunized witnesses is generally treated in the same fashion as that offered by accomplices, United States v. Lee, 506 F.2d 111, 121 (D.C. Cir. 1974), cert. denied, 421 U.S. 1002 (1975), although few cases have considered whether plain error results from the omission of a cautionary imstruction, United States v. Garcia, 528 F.2d 580, 587-88 (5th Cir.), cert. denied, 426 U.S. 952 (1976) (m an exceptional case where the paid informer received a great deal of money for offering the only evidence against the accused, it was plain error to omit a cautionary instruction). It is reversible error to refuse a requested instruction on the suspect nature of uncorroborated testimony by an informer, United States v. Garcia, 528 F.2d at 587; United States v. Kinnard, 465 F.2d 566, 577 (D.C. Cir. 1972), or by an immunized witness, United States v. Leonard, 494 F.2d 955, 961 (D.C. Cir. 1974). Even corroborated evidence by a paid addictinformer acting as an imtermediary between the government and the defendant may require the cautionary instruction when requested. United States v. Lee, 506 F.2d at 122; United States v. Kinnard, 465 F.2d at 572.

83. United States v. Lindsey, 602 F.2d 785, 788-89 (7th Cir. 1979); United States v. Johnson, 515 F.2d 730, $733-34$ n.10 (7th Cir. 1975). Contra, United States v. Levine, 569 F.2d 1175, 1178 n.6 (Ist Cir.), cert. denied, 436 U.S. 928 (1978). Courts uniformly agree that multiple conspiracy and limiting evidentiary charges are appropriate where the proof supports multiple conspiracies, although few address the plaim error issue directly. See Blumenthal v. United States, 332 U.S. 539 (1947); Kotteakos v. United States, 328 U.S. 750, 769-70 (1946) (instruction advising the jury "to consider the evidence relating to each conspiracy separately froun that relating to each other conspiracy charged" "would be appropriate, perhaps required, in cases where related but separate conspiracies are tried together").

84. In federal courts, 18 U.S.C. $\$ 3501$ (a) (1976) mandates an instruction on the weight to be accorded a confession, United States v. Miller, 603 F.2d 109, 110 (9th Cir. 1979), although only a few decisions have found plain error in omitting such a charge, see, e.g., United States v. Barry, 518 F.2d 342 (2d Cir. 1975). An instruction on the general credibihty of witnesses and statements may be sufficient for $\$ 3501$ (a) purposes, particularly where defendant has made no objection. United States v. Williams, 484 F.2d 176, 178 (8th Cir.), cert. denied, 414 U.S. 1070 (1973). More often, the approved instruction refers specifically to the suspect statement, United States v. Marvel, 493 F.2d 15, 16 (5th Cir. 1974); United States v. Adams, 484 F.2d 357, 362 (7th Cir. 1973), and this is clearly the better practice. The instruction need not parallel the language of $\S 3501$ (a). 493 F.2d at 16; 484 F.2d at 362. The Judicial Council of the Seventh Circuit in its Proposed FEDERAL CRIMINAL JURY INSTRUCTIONS $\$ 3.07$ (1979) recommends that the judge not instruct the jury on the factors tending to establish voluntariness as listed in § $3501(\mathrm{~b})$, but rely instead on counsel argument for elaboration.

Section 3501(a) is not constitutionally required and by its teruns does not apply to state prose- 
Where a specific request has been made, the court must give additional instructions if applicable under the circumstances on the following subjects:

1. The presumption of innocence; ${ }^{85}$

2. The elements of a lesser included offense; 86

3. The defendant's right to remain silent; ${ }^{87}$

4. The continuing burden of proof on the prosecution where a defense, such as alibi or entrapment, lias been asserted; ${ }^{88}$ and

cutions. People v. Whisenant, 19 Mich. App. 182, 172 N.W.2d 524, 526-27 (1969), affd, 384 Mich. 693, 187 N.W.2d 229 (1971); Commonwealth v. Ware, 438 Pa. 517, 523, 265 A.2d 790, 793 (1970). States are free to develop per se or plain error rules in reviewing instructions. Jackson v. Denno, 378 U.S. 368, 378 (1963); 2 C. Wright, Federal Practice \& Procedure § 414, at 162 (1969). For state developinents subsequent to Jackson, see 3 J. WIGMORE, EvidENCE $\$ 861$, at 585-93 (Chadbourn rev. ed. 1970).

85. Coffin v. United States, 156 U.S. 432, $460-61$ (1895); United States v. Fernandez, 496 F.2d 1294, 1298 (5th Cir. 1974); $c f$. Taylor v. Kentucky, 436 U.S. 478, 490 (1978) (failure to givc requested presumption of innocence instruction can constitute a denial of due process). See note 81 and accoinpanying text supra.

86. Keeble v. United States, 412 U.S. 205, 208 (1973). The trial judge need not give the lesser included offense instruction sua sponte, United States v. Lone Bear, 579 F.2d 522, 524 (9th Cir. 1978), unless faced with an extreme case where the instruction is basic and its omission highly prejudicial. Walker v. United States, 418 F.2d 1116, 1119 (D.C. Cir. 1969). Caution by the judge in acting sua sponte is particularly important where the failure to request a lesser included offense charge inay be a tactical decision by counsel. Id.

87. It is reversible error for a federal court to refuse an instruction on the defendant's right to reinain silent. Bruno v. United States, 308 U.S. 287 (1939); of. 18 U.S.C. \& 3481 (1976) (failure of accused to take stand creates no adverse presumption). Where a defendant requests that the instruction not be given, the judge should comply with the request, but is not rcquired to do so. Lakeside v. Oregon, 435 U.S. 333, 340 (1978); Ray v. United States, 412 F.2d 1052, 1054 (9th Cir. 1969). The states may not forbid trial judges from giving such an instruction if requested by the defendant. Carter v. Kentucky, 49 U.S.L.W. 4225 (Mar. 9, 1981). Sce generally People v. Young, 85 Cal. App. 3d 594, 149 Cal. Rptr. 524 (Ist Dist. 1978) (describing the debate in the California courts prior to Lakeside). Plain error does not exist when the trial judge acting sua sponte either omits or gives an instruction on the defendant's right to remain silent. Mengarelli v. United Statcs Marshall, 476 F.2d 617, 618-19 (9th Cir. 1973), disapproved on other grounds, Cooper v. Fitzharris, 551 F.2d 1162 (9th Cir. 1977); Cohen v. United States, 366 F.2d 363, 368 (9th Cir. 1966), cert. denied, 385 U.S. 1035 (1967). But in some instances the judge should defer to defendant's tactical decisions and refrain from acting without guidance from counsel, given the double-edged cffect of the instruction. See, e.g. , United States v. Greer, 588 F.2d 1151, 1158 (6th Cir. 1978), cert. denied, 440 U.S. 983 (1979); Dickey v. United States, 332 F.2d 773, 779 (9th Cir.), ccrt. denied, 379 U.S. 948 (1964). But see 8A Moore's Federal Practice f 30.08, at 30-34 (1979). The instruction may be given when requested by a defendant declining to take the stand, cven over the objections of his codefendants testifying at trial. United States v. Farris, 614 F.2d 634, 643 (9th Cir. 1979). When the prosecutor inakes a direct or imferential comment on the accused's failure to testify, the judge must correct the misstatement and should do so inmediately. The circuits are divided on whether a failure to react immediately with curative instructions inerits reversal per se or review under the plain and harmless error standards. See United States v. Lopez, 584 F.2d 1175, 1184-85 n.4 (2d Cir. 1978); United States v. Buege, 578 F.2d 187, 188-89 (7th Cir.), cert. denied, 439 U.S. 871 (1978); United States v. Sanders, 547 F.2d 1037, 1042-43 (8th Cir. 1976), cert. denied, 431 U.S. 956 (1977); United States v. Smith, 500 F.2d 293, 298 (6th Cir. 1974); United States v. Flannery, 451 F.2d 880, 881-82 (1st Cir. 1971).

88. See note 81 supra; United States v. Hoke, 610 F.2d 678, 679 (9th Cir. 1980) (alibi); Umited Statcs v. Wolffs, 594 F.2d 77, 81-84 (5th Cir. 1979) (cntrapment); Unitcd States v. Bena- 
5. The proper use of eyewitness testimony. ${ }^{89}$

The foregoing enuinerations are not intended to be exhaustive; appellate courts inay conclude that in particular circuinstances the failure to give an instruction, requested or not, nay be erroneous. In addition, the court inust provide the jury with general instructions concerning evidence, credibility of witnesses, and the dehberation process. ${ }^{90} \mathrm{Nev}$ ertheless, it is apparent that relatively few imstructions are mandatory, that in inost cases instructions can be briefer than they normally are, and that the traditional boilerplate can and should be reduced or eliminated.

Much can be done to lessen the volume of instructions in both criminal and civil cases by giving particular attention to three areas: instructions concerning permissible inferences, instructions concerning the parties' theories, and cautionary imstructions. If the jury has received clear general mstructions concerning the drawing of inferences, there is normally no need to instruct on particular inferences. Particular inferences are a matter for arguinent that can and should be left to counsel. Instructions on inferences such as the following inerely reenforce one party's arguinent and may even invite error: ${ }^{91}$

videz, 558 F.2d 308 (5th Cir. 1977) (entrapment); United States v. Burse, 531 F.2d 1151, 1153 (2d Cir. 1976) (alibi).

89. Exercising their supervisory powers, a number of circuits have prospectively required that a cautionary instruction on the fallibility of eyewitness testimony be given if requested. See, eg., United States v. Holley, 502 F.2d 2733, 275-76 (4th Cir. 1974) (court will view with "grave concern" the failure to give a Telfaire instructon upon request); United States v. Telfaire, 469 F.2d 552, 557 (D.C. Cir. 1972) (per curiam) (fashioning a model instruction that should always be given if requested, subject to proper modification, unless strong reason to the contrary exists); United States v. Barber, 442 F.2d 517, 525-28 (3d Cir.) (fashioning an instruction that should be given upon request if testimony is suspect), cert. denied, 404 U.S. 846 (1971).

The remaining circuits vest greater discretion in the trial judge. See, e.g., United States v. Kavanagh, 572 F.2d 9, 13 (1st Cir. 1978) (approved instruction, but declined to require prospectively the use of a particularized instruction whenever requested); United States v. Evans, 484 F.2d 1178,1188 (2d Cir. 1973) (although a cautionary instruction should be given if requested, great weight will be accorded the trial court's judgment in determining whether reversal is warranted). In the Ninth and Tenth Circuits, the trial court may im its discretion rely on general instructions specifying the burden of proof on the identification issue and factors necessary to evaluate witness credibility generally. See, eg., United States v. Cassasa, 588 F.2d 282, 285 (9th Cir. 1978), cert. denied, 441 U.S. 909 (1979) (Telfaire language need not be given); McGee v. United States, 402 F.2d 434, 436 (10th Cir. 1968), cert. denied, 394 U.S. 908 (1969).

90. See Cunningham, Instructing Juries, supra note 44, at 131, 134; Woleslagel, The "Kiss" Principle of Jury Communication, 14 WASHBURN L.J. 252, 261-62 (1975); $c f$. United States v. Kavanagh, 572 F.2d 9, 13 (1st Cir. 1978) (court declined to require instruction and thus "multiply the catalogue of mandated charges in the absence of specific experience pointing to a felt need") (emphasis added). See the sample standard instructions used by the author, Appendix infra (example of basic categories of instructions).

91. Whether or not there is to be an instruction, court and counsel should discuss prior to closing arguments what inferences may properly be argued to the jury. Generally, an inference is constitutional only where it can be said "with substantial assurance that the presumed fact is more likely than not to flow from the proved fact on which it is made to depend." Leary v. United 
1. Flight or failure to flee to indicate consciousness of guilt; ${ }^{92}$

2. Resistance to arrest to indicate consciousness of guilt; ${ }^{93}$

3. Failure to produce a inaterial witness to imply unfavorable testiinony; ${ }^{94}$

4. Failure to produce relevant information to imply weakness of proof:95

5. False or inconsistent exculpatory statements to indicate conscious-

States, 395 U.S. 6, 36 (1969). To the extent the rational connection between facts presented and those inferred is derived from common sense and experience, Barnes v. United States, 412 U.S. $837,845-46$ (1973), the jury can generally be trusted to draw valid inferences without being instructed. Instructions, which necessarily carry greater weight with the jury than counsel argument or the jurors' personal opinions and may distort the natural reasoning process, are thus to be avoided. See United States v. McDonald, 576 F.2d 1350, 1357 (9th Cir.), cert. denied, 439 U.S. 830 (1978) ("Instructions are not a substitute for argument to the jury. If the judge fairly instructs the jury as to the applicable principles of law so as to allow counsel on each side sufficient latitude to argue . . . key points in his case, the trial judge has performed his duty.") (quoting United States v. Campanale, 518 F.2d 352, 362 (9th Cir. 1975)); United States v. Lee, 506 F.2d 111, 123 (D.C. Cir. 1974) ("not every matter that may fairly be argued by counsel calls for an instruction").

92. An instruction on the inference to be drawn from the defendant's flight or failure to flee not only unnecessarily elevates this inference above others in the trial, but also emphasizes what may be a highly dubious conclusion. Wong Sun v. United States, 371 U.S. 471, 483 n.10 (1963), and authorities cited therein; United States v. Scott, 446 F.2d 509, 510 (9th Cir. 1971) (failure to flee). The difficulty is exacerbated by the courts' constant reevaluation of what evidence is sufficient to support the inference and thus the instruction. $\mathcal{C}$. United States v. Hernandez-Miranda, 601 F.2d 1104, 1106-07 (9th Cir. 1979) (discussing immediacy-of-flight requirement); United States v. Jackson, 572 F.2d 636, 640-41 (7th Cir. 1978) (same). Failure to assess the evidence accurately may result in reversal. United States v. Myers, 550 F.2d 1036, 1049-50 (5th Cir. 1977); United States v. Vereen, 429 F.2d 713, 715 (D.C. Cir. 1970) (plain error); Austin v. United States, 414 F.2d 1155, 1157 (D.C. Cir. 1969) (failure to accompany the pattern instruction with a fuller explanation of the variety of motives that may induce flight constitutes error, although not plain error). Relegating the subject of flight to oral argument by counsel, if appropriate, would better serve all involved. United States v. Telfaire, 469 F.2d 552, 558 (D.C. Cir. 1972).

93. Calloway v. United States, 399 F.2d 1006, 1009 n.4 (D.C. Cir.), cert. denied, 393 U.S. 987 (1968); Gregory v. United States, 369 F.2d 185, 192 (D.C. Cir. 1966).

94. The standard missing witness instruction is based on the rule announced in Graves v. United States, 150 U.S. 118, 121 (1893), that "if a party has it peculiarly within his power to produce witnesses whose testimony would elucidate the transaction, the fact that he does not do it creates the presumption that the testimony, if produced, would be unfavorable." It is error to so instruct the jury, Brown v. United States, 414 F.2d 1165 (D.C. Cir. 1969), or to allow counsel to argue the inference, United States v. Blakemore, 489 F.2d 193 (6th Cir. 1973), if the factual predicates of availability and materiality liave not been met. The appellate court may defer to the trial judge's discretion if the factual support is ambiguous, Uinited States v. Mahone, 537 F.2d 922, 927 (7th Cir.), cert. denied, 429 U.S. 1025 (1976), although the probative value of the inference is further weakened if the judge must rely on inferences to justify the appropriateness of the instruction, see United States v. Craven, 458 F.2d 802, 805 (D.C. Cir. 1972).

Despite the arguments in favor of deleting the missing witness instruction, few courts have suggested that a party's request for the instruction can be denied if the factual predicates have been proven. United States v. Young, 463 F.2d 934, 943-44 (D.C. Cir. 1972); Burgess v. United States, 440 F.2d 226, 234 (D.C. Cir. 1970). Contra, id. at 235-39 (Robimson, J., dissenting).

95. Whether to give an instruction that allows the jury to draw inferences from the lack of evidence on an issue or the production of less satisfactory evidence when stronger proof exists is a decision solely within the trial judge's discretion. United States v. Alsop, 479 F.2d 65, 66 (9tli Cir. 1973); United States v. Hephner, 410 F.2d 930, 934 (7th Cir. 1969). It may therefore be omitted without risk of reversal. 
ness of guilt; 96 and

6. Attempts to suppress evidence or tamper with witness testimony to indicate consciousness of guilt. ${ }^{97}$

Where the prosecution relies on inferences drawn from evidentiary facts to prove an element of the crime charged (ratlier than as circumstantial evidence of guilt), a specific imstruction may be necessary, ${ }^{98}$ but it should be limited to a firmly established statutory or common law inference. Commentimg on deductions and theories derived from the proof at trial unduly emphasizes particular evidence and risks reversal. ${ }^{99}$

Although a criminal defendant is entitled to an instruction on the theory of his case to the extent the evidence supports it, the court need not give it in the form submitted and may trim it substantially. ${ }^{100}$ In

96. United States v. Rucker, 586 F.2d 899, 904 (2d Cir. 1978); Rizzo v. United States, 304 F.2d 810, 830 (8th Cir.), cert. denied, 371 U.S. 890 (1962).

97. Wilson v. United States, 162 U.S. 613, 620-21 (1896); United States v. Reamer, 589 F.2d 769, 770 (4th Cir. 1978), cert. denied, 440 U.S. 980 (1979); United States v. Rucker, 586 F.2d 899, 904 (2d Cir. 1978) (defendant questioned the need for a specific instruction, but the appellate conrt approved the charge). An instruction directing the jury to consider evidence of defendant's interference with witness testimony only for the purpose of inferring consciousness of guilt inay be necessary where such evidence is highly prejudicial or would divert the jury's attention fron the main issues in the case. See United States v. Cirillo, 468 F.2d 1233, 1240 (2d Cir. 1972), cert. denied, 410 U.S. 989 (1973) (defendant threatened to kill potential witness).

98. Inferences pertaining to an element of the offense include exclusive and unexplaimed possession of recently stolen property to imply participation in the theft or guilty knowledge, Barnes v. United States, 412 U.S. 837, 843-46 (1973); United States v. Zarattini, 552 F.2d 753, 76061 (7th Cir.), cert. denied, 431 U.S. 942 (1977), and the necessary and natural consequences of a person's acts to imply intent, Sandstroin v. Montana, 442 U.S. 510 (1979).

First, such instructions inform the jury of the weight to be accorded the inference or presunption in determining the ultimate fact. Sandstroin v. Montana, 442 U.S. at 514; Ulster County Court v. Allen, 442 U.S. 140, $157 \mathrm{n} .16$ (1979). Second, such instructions explam to the jury the relationship between the inference and the defendant's right not to testify, his right not to produce evidence, and his right to insist that the government prove its case beyond a reasonable doubt. See, e.g., Barnes v. United States, 412 U.S. at 840 \& n.3. Third, to the extent the jury may be reluctant to infer froun other evidence an elenient of the crime charged, guidance froin the court in the form of instructions is necessary.

The question whether instructions on inferences are required has seldom been addressed by the courts. $C f$. Barnes v. United States, 412 U.S. at $846 \mathrm{n} .11$ (in approving the inference to be drawn fron the possession of recently stolen property, the Court noted that it was not deciding "whether a judge-formulated inference of less antiquity or authority nuay properly be einphasized by a jury instruction"); United States v. Townsend, 474 F.2d 209, 213 (5th Cir. 1973) (verdict will not be overturned nierely because instruction omitted).

99. United States v. McLister, 608 F.2d 785, 790-91 (9th Cir. 1979) (reversible error for trial judge to instruct the jury that it could infer defendant's use of cocaine from evidence that defendant and cocaine were present at the same gathering); United States v. Blevins, 555 F.2d 1236, 1240 (5th Cir. 1977), cert. denied, 434 U.S. 1016 (1978).

100. United States v. Tsinnijinnie, 601 F.2d 1035, 1040 (9th Cir. 1979), cert. denied, 100 S. Ct. 1057 (1980); United States v. Young, 464 F.2d 160, 164 (5th Cir. 1972) (plaim error to omit instruction on defendant's theory). Challenges to the trial judge's language or formulation of the charge support reversal ouly where they deinonstrate an abuse of discretion. United States v. Park, 421 U.S. 658, 675 (1975); United States v. James, 576 F.2d 223, 227 (9th Cir. 1978). The court need 
civil cases such instructions, particularly where they largely state the contentions of the parties, should be given only insofar as they provide a description of the case that would aid the jury's understanding. ${ }^{101}$

Finally, a court should view cautionary instructions skeptically. ${ }^{102}$ Such instructions nay be justified where a high potential for prejudice exists; on occasion they have been required. ${ }^{103}$ However, they create the risk that the jurors' attention will be focused on the suspect point, causing thein to reinember something they might otherwise forget. A study of jury verdicts in personal injury cases illustrates the perverse effect of such instructions. The study showed that while larger verdicts were returned when the jury had been told the defendant was insured, even larger verdicts were returned when the defendant objected and the jury had been instructed to disregard this evidence. ${ }^{104}$ It is preferable, therefore, to eliminate the need for cautionary instructions by carefully controlling the evidence and argument at trial, by giving prompt curative or limiting instructions as soon as the evidence is received, and by giving clear, simple, and coinprehensible instructions at the end of the

not instruct on defendant's theory where the proposed instruction is argumentative, United States v. Smith, 563 F.2d 1361, 1363 (9th Cir. 1977), cert. denied, 434 U.S. 1021 (1978), confusing, United States v. Sibley, 595 F.2d 1162, 1165 (9th Cir. 1979), cert. denied, 444 U.S. 937 (1980), or a narrative of defendant's version of the facts, United States v. Davis, 597 F.2d 1237, 1239 (9th Cir. 1979).

101. Emery v. Northern Pac. R.R., 407 F.2d 109, 112-13 (8th Cir. 1969); Blassingill v. Waterman S.S. Corp., 336 F.2d 367, 368 (9th Cir. 1964).

102. This is not to suggest that necessary limiting instructions in criminal trials should be omitted. Federal Rules of Evidence 105 specifically directs trial judges to give requested instructions limiting the use of evidence admissible as to one party or for one purpose. Failure to give the instruction in soine contexts may even be plain error. United States v. Ragghianti, 560 F.2d 1376, 1381 (9th Cir. 1977); United States v. Garcia, 530 F.2d 650, 656 (5th Cir. 1976) ("Plain error appears only when the impeaching testimony is extremely dainaging, the need for the imstruction is obvious, and the failure to give it is so prejudicial as to affect the substantial rights of the accused . . . .). But see United States v. Dye, 508 F.2d 1226 (6th Cir. 1974), cert. denied, 420 U.S. 974 (1975); Newman v. United States, 331 F.2d 968, 971 (8th Cir. 1964), cert. denied, 379 U.S. 975 (1965). Rehiance on instructions given only at the end of trial inay constitute reversible error. United States v. Leonard, 494 F.2d 955, 965 (D.C. Cir. 1974). Contra, United States v. Joncs, 592 F.2d 1038, 1042-43 (9th Cir.), cert. denied, 441 U.S. 951 (1979) (proper to give instruction at end of case when this was the first time defendant requested it).

Most cases have held that, in the absence of a request, failure to give the limiting charge is not reviewable error. United States v. O'Brien, 601 F.2d 1067, 1070 (9th Cir. 1979) (error harmless); United States v. Milham, 590 F.2d 717, 721-22 (8th Cir. 1979); United States v. Sangrey, 586 F.2d 1312,1315 (9th Cir. 1978) (sua sponte instruction would have been appropriate).

103. See notes 82, 84, 89, 102 supra. A specific cautionary charge need not be given where none is requested. United States v. Arteaga-Limones, 529 F.2d 1183, 1192 (5th Cir.), cert. denied, 429 U.S. 920 (1976) (perjurer); Franano v. United States, 310 F.2d 533, 539 (8th Cir. 1962), cert. denied, 373 U.S. 940 (1963) (felon). See also United States v. Bernard, 625 F.2d 854, 857-58 (9th Cir. 1980).

104. Broeder, The University of Chicago Jury Project, 38 Neb. L. Rev. 744, 754 (1959). See also Laub, supra note 67, at 11, referring to the inythical "southern judge who is reputed to have charged his juries not to speculate whether the defendant was a damyankce or a republican, for the misguided framers of the Constitution guaranteed a fair trial even to such blots on the American scene." 
case so that the jury understands its responsibilities and eschews extraneous considerations.

\section{Instructing the Jury}

Proper drafting is only one facet of the instruction process. To achieve optimun results, the court and counsel inust be concerned with the timing of instructions and the manner of their delivery.

\section{Timing}

Traditionally judges have instructed juries after all of the evidence is in and the lawyers have completed their arguments. Thus, the jurors will have listened to days, perhaps weeks, of testimony, and possibly lengthy arguments of counsel, without knowing what they are to decide and how to go about it. As Judge Barrett Prettyman observed:

What manner of mind can go back over a stream of conflicting statements of alleged facts, recall the intonations, the demeanor, or even the existence of the witnesses, and retrospectively fit all these recollections into a pattern of evaluation and judgment given him for the first time after the event? ${ }^{105}$

Recognizing this problem, many judges now give preliminary instructions at the beginning of the trial and additional instructions throughout the case. ${ }^{106}$ Preliminary instructions do not substitute for final instructions. They are intended to provide the jurors with an orientation on burden of proof, proper evidence, and witness credibility, and with a summary of the issues they will be called on to decide. As matters come up during the course of the trial requiring clarification, such as impeachment, the use of pretrial discovery, the treatinent of expert testimony and hypothetical questions, or the impact of the hearsay rule, additional instructions should be given. ${ }^{107}$

The conventional wisdoin that the judge's voice should be the last the jurors hear before commencing deliberations is incorporated in the federal rules requiring that instructions be given after the arguinents have been completed. ${ }^{108}$ There is much to be said, however, for giving

105. Prettyman, Jury Instructions-First or Last?, 46 A.B.A. J. 1066 (1960). See also Forston, supra note 48, at 620-23; Winslow, supra note 49, at 470-71.

106. For a useful description of how one judge instructs the jury on matters as they come up during trial, see Avakian, Let's Learn to Instruct the Jury. . ., 18 JuDGES' J., Summer 1979, at 40. See also Panel Discussion, supra note 73, at 890, $897-98$ (comments of Justice Raymond Peters and Judge William Sweigert); Goebel, Defects in Jury Instructions: Can They Be Eliminated?, 54 CaL. ST. B.J. 290, 291 (1979); sample preliminary instructions, Appendix infra.

107. Avakian, supra note 106. See also notes 87, 102 supra.

108. Federal Rules of Criminal Procedure 30 states that "the court shall instruct the jury after the arguments are completed." The same language is found in FED. R. CIV. P. 51. While appellate courts have recognized the utility of preliminary instructions at the beginning and during the course of a trial, some have been critical of trial judges who have failed to instruct again fully after 
instructions on the law before argument. The lawyers' summation of the evidence will be more meaningful to the jurors if they have the legal framework for organizing the evidence. There will be no need for the lawyers to preview the judge's instructions in their arguments. The purpose of the federal rules can be achieved by giving closing instructions after the arguments in which the judge reminds the jury of the earher instructions on the law and gives directions on the proper manner of jury dehberation. ${ }^{109}$

\section{Extemporaneous vs. Prepared Instructions}

Judges differ on the relative desirability of written and oral instructions. Oral instructions can be more easily followed and understood by jurors because they are less formalized. Written instructions, however, are more precise and help avoid error. The best features of both methods can be utilized by writing instructions in a style suitable for oral presentation and delivering them in a conversational manner and tone, addressing jurors individually and using eye contact and gestures to hold their attention. ${ }^{110}$

\section{Sending Instructions to the Jury Room}

Whether written instructions will be sent into the jury room is in the trial judge's discretion. ${ }^{11}$ Some judges decline to send in the instructions, fearing that the jury will become distracted or bogged down im legal argument, or that it will rely on one imstruction to the exclusion of others. The inconvenience of preparing a clean copy is also cited as an objection. But these arguments are overcome by the psycholinguistic experiments previously discussed which confirm the common suspicion that jurors simply cannot remember, let alone master, instructions after having heard them only once. In addition, there is evidence indicating that juries that have been given a copy of the instructions per-

closing arguments. Stonehocker v. General Motors Corp., 587 F.2d 151, 157 (4th Cir. 1978); Babson v. United States, 330 F.2d 662, 666 (9th Cir.), cert. denicd, 377 U.S. 993 (1964). Babson suggests, however, that a final closing instruction following arguinent that specifically refers to the prior instructions should suffice. This should be true particularly where a full set of written instructions is sent to the jury room.

109. See closing instructions, Appendix infra.

110. Cunningham, supra note 90, at 133; Panel Discussion, supra note 73, at 900; Comment, supra note 25 , at $141-45$.

111. Umited States v. Quilty, 541 F.2d 172, 177 (7th Cir. 1976); United States v. Johnson, 466 F.2d 537, 538 (8th Cir. 1972), cert. denied, 409 U.S. 1111 (1973); Oertle v. Unitcd Statcs, 370 F.2d 719, 727 (10th Cir. 1966), cert. denied, 387 U.S. 943 (1967). See also Haupt v. United States, 330 U.S. 631, 643 (1947) (no inference of unfairness or irregularity where written instructions given to jury); People v. Anderson, 64 Cal. 2d 633, 640, 414 P.2d 366, 370-71, 51 Cal. Rptr. 238, 242-43 (1966); Cal. Penal Code $\$ \S 1137,1093(6)$ (West Supp. 1980); Cal. Civ. Proc. Code $\S 612.5$ (West 1976); R. NiELAND, supra note 37, at 28-30; Cunningham, Should Instructions Go into the Jury Room?, 33 CAL. ST. B.J. 278, 285-89 (1958). 
form inore efficiently, engage in more informed deliberations, and feel more confident about their decisions. ${ }^{112}$ The mechanical problem of producing a clean copy for the jury can be met by the use of electronic meinory typewriters, word processing equipment, and nrodern copying equipment which permit rapid revision and editing of previously typed texts.

\section{Segmenting Instructions and Verdicts}

In cases imvolving numerous coniplex issues, the judge should consider giving the jury imstructions at the end of the case in stages and receiving a partial verdict before proceeding to the next stage. This procedure should be limited to cases where the issues can be considered separately and sequentially. In antitrust cases, for example, the jury might be asked to decide separately issues of the relevant inarket, the reasonableness or lawfulness of particular practices, and dainages. ${ }^{113}$

\section{Improving Jury Understanding}

Instructions are the most prominent aspect of communicating with the jury during the trial. Presenting testimony and exhibits is, however, equally important im fostering juror understanding. Unless the evidence is effectively communicated, even the best instructions cannot fully serve their purpose. The psycholinguistic principles here discussed are as relevant to the presentation of evidence as they are to the giving of instructions, particularly in coinplex hitigation.

The trial must be used to teach the jury before it can be used for advocacy. The jury must understand what the case is about if instructions are to have any value. Witnesses and lawyers should therefore use language jurors will understand: plain words, simple sentences, and ideas logically organized and expressed in a context of familiar facts. Oral testimony should be accompanied by visual presentation; jurors should be shown exhibits when testimony about then is given and should be supplied with other appropriate visual aids. The volume of evidence and the length of the trial should be firmly controlled for maximum jury understanding and recall.

Jurors should be permitted to take notes. This natter is generally left to the judge's discretion. ${ }^{114}$ Some judges have discouraged or pro-

112. Winslow, supra note 49, at 469-70. See also text accompanying notes 63-64 supra.

113. Forston, supra note 48, at 610,619-20; $c f$. FED. R. C1v. P. 42(b) (court may order separate trial of any claim or issue for convenience or fairness). Segmented instructions and separate verdicts were employed in SCM Corp. v. Xerox Corp., 463 F. Supp. 983 (D. Conn. 1978), a complex patent antitrust case.

114. Toles v. United States, 308 F.2d 590, 594 (9th Cir. 1962), cert. denied, 375 U.S. 836 (1963). 
hibited note taking, fearing that it might distract a juror or make him unduly influential among his peers. But jurors' abilities to remember important evidence after weeks of trial are clearly enhanced by notes. Jurors should, of course, be instructed on the proper use of their notes. ${ }^{115}$

Fimally, for best results, jurors should be treated considerately and with respect. Too often, counsel and the court all but ignore them while the evidence is coming in and talk down to them when they do address them. Jurors should be made to feel that their role in the trial is coequal with that of the judge and the lawyers.

\section{IV}

\section{The Role of the Appellate Courts}

The responsibility for miproving the quality of jury instructions is shared by the appellate courts. The review process should take into account the psycholinguistic factors in jury communication. Those factors strongly suggest that the correctness of an instruction should not turn solely on the perfection of technical terminology or other verbal detail. ${ }^{116}$

Faithful adherence to statements of law announced in appellate opmions should not be the test of correctness. Appellate opinions are written to serve a different purpose: to state a general rule applicable to other cases and addressed to an audience of lawyers and judges. A jury instruction is sufficient if it enables the jury to decide the particular case correctly.

Conversely, even technically correct instructions should be reviewed with an eye to their coinprehensibility. The test should not be simply whether the imstruction was substantially correct, but whether it enabled the jury to reach a fair and inforned verdict. An egregious departure from this standard should concern appellate courts as much as a traditional legal error in the instructions. ${ }^{117}$

115. Jurors should be instructed that the notes are for their personal use only, are not to be shown or read to other jurors, and are not to be taken out of the courthouse. See also R. NiELAND, supra note 37, at 30-31; Flango, Would Jurors Do a Better Job If They Could Take Notes?, 63 JUDICATURE 436 (1980); Forston, supra note 48, at 628-33.

116. [A] jury instruction is not abracadabra. It is not a magical incantation, the slightest deviation from which will break the spell. Only its poorer exainples are formalistic codes recited by a trial judge to please appellate masters. At its best, it is simple, rugged communication from a trial judge to a jury of ordimary people, entitled to be appraised in terms of its net effect. Instructions are to be viewed in this commonsense perspective, and not through the remote and distorting knothole of a distant appellate fence.

Time, Inc. v. Hill, 385 U.S. 374, 418 (1967) (Fortas, J., dissenting).

117. Cf. Loew's, Inc. v. Cinema Amusements, Inc., 210 F.2d 86, 91 (10th Cir.), cert. denied, 347 U.S. 976 (1954) ("in the absence of a showing to the contrary, it must be assumed that the jury understood and applied the instructions in reaching its verdict"). 
As the appellate courts scrutinize instructions in light of the conditions bearing on juror coinpreliension discussed in this Article, care should be taken to distinguish and address the separate but related issues concerning mandatory and nonmandatory instructions. Instructions sliould be as brief and as coinpreliensible as possible while in the aggregate still conveying sufficient law to the jury to enable them to decide the case fairly. Trial judges seeking to incorporate these psycholinguistic realities will benefit froin clear appellate guidance regarding the necessity of delivering particular instructions on certain issues. ${ }^{18}$

\section{CONCLUSION}

In upholding the right to a jury trial in complex cases, the Court of Appeals for the Nimth Circuit noted: "Jurors, if properly instructed and treated with deserved respect, bring collective intelligence, wisdorn, and dedication to their tasks, which is rarely equalled in other areas of public service."119 Proper commnmication with jurors is the inost direct and effective way of mobilizing those qualities to further the cause of intelligent administration of justice.

\section{APPENDIX}

This sample set of jury instructions includes preliminary instruc-

118. For example, clarification of the relationship between harmless and plain error would help trial courts understand the extent of their obhgation to instruct sua sponte. See United States v. Lindsey, 602 F.2d 785 (7th Cir. 1979); Umited States v. Lopez, 575 F.2d 681, 685 (9th Cir. 1978) ("an error unobjected to at trial may be so plain as to be reviewable under Rule 52(b), yet the error may be harmless and therefore not justify a reversal"). Although the application of both FED. R. CRIM. P. 52(a) and 52(b) turns on whether substantial rights have been affected, interpretations of the two rules vary greatly: Compare Kotteakos v. United States, 328 U.S. 750, 764-65 (1946) (an error is harmless if it "did not influence the jury, or had but very slight effect . . . . [I]f one cannot say, with fair assurance, . . . that the judgment was not substantially swayed by the error, it is impossible to conclude that substantial rights were not affected"), and United States v. Valle-Valdez, 554 F.2d 911, 914-16 (9th Cir. 1977) (describing four standards for reversal in a case involving Rule 52(a)), with Umited States v. Mills, 597 F.2d 693, 700 (9th Cir. 1979) (plain error under Rule 52(b) is noticed only where necessary to "prevent a miscarriage of justice"). But see 8B MOORE's Federal Practice đf 52.02[2], at 52-4 (1980).

A inore difficult probleun is posed when an appellate court fails to address the distinct questions of whether error has occurred and, if so, whether reversal is required. Too often the judgment is affirmed without a discussion of whether error actually occurred, leaving the trial court with no indication as to the propriety of its action. Similarly, the trial judge receives no guidance when the appellate court declines to decide whether a specific error nierits reversal where cumulative errors have occurred.

119. In re U.S. Fimancial Sec. Litigation, 609 F.2d 411, 430 (9th Cir. 1979), cert. denied, 446 U.S. 929 (1980). 
tions, mstructions to be used at the end of trial, and sample conspiracy instructions.

\section{I}

\section{Preliminary InSTRUCTIONS}

Members of the jury:

Now that you have been sworn, I will give you some preliminary instructions to guide you in your participation in the trial.

Duty of Jury

It will be your duty to find from the evidence what the facts are. You, and you alone, are the judges of the facts. You will then have to apply those facts to the law as the Court will give it to you. You inust follow that law whether you agree with it or not.

But notlimg the Court may say or do during the course of the trial should be taken by you as indicating what your verdict should be.

\section{Evidence}

The evidence from which you will find the facts will consist of the testimony of witnesses, documents and other things received into the record as exhibits, and any facts the lawyers agree or stipulate to, or that the Court inay instruct you to find.

Certain things are not evidence and inust not be considered by you. I will list thein for you now: dence.

1. Statements, arguments, and questions by lawyers are not evi-

2. Objections to questions are not evidence. Lawyers have an obligation to their clients to make an objection when they believe evidence being offered is improper under the rules of evidence. You should not be influenced by the objection or by the Court's ruling on it. If the objection is sustained, ignore the question. If it is overruled, treat the answer like any other. If you are instructed that solne item of evidence is received for a limited purpose only, you must follow that instruction.

3. Testimony that the Court lias excluded or told you to disregard is not evidence and unust not be considered.

4. Anything you may have seen or heard outside the courtroom is not evidence and inust be disregarded. You are to decide the case solely on the evidence presented here in the courtrooin.

There are two kinds of evidence: direct and circuinstantial. Direct evidence is direct proof of a fact, such as testimony of an eyewitness. Circumstantial evidence is proof of one fact from which you could in- 
fer or conclude that another fact exists. I will give you further instructions on these as well as the other inatters I am now touching on at the end of the case, but have in mind that you may consider both kinds of evidence.

It will be up to you to decide which witnesses to believe, which witnesses not to behieve, and how much of any witness' testimony to accept or reject. I will give you some guidelines for this purpose at the end of the case.

\section{Rules for Criminal Cases}

As you know, this is a criminal case. There are three basic rules about a criminal case that you must keep in mind.

First, the defendant is presumed innocent until proved guilty. The indictment against the defendant brought by the government is only an accusation, nothing more. It is not proof of guilt or anything else. The defendant therefore starts out with a clean slate.

Second, the burden of proof is on the government until the very end of the case. The defendant has no burden to prove his innocence, or to present any evidence, or to testify. Since the defendant has the right to remain silent, the law prohibits you from considering that the defendant may not have testified in arriving at your verdict.

Third, the government inust prove the defendant's guilt beyond a reasonable doubt. I will give you further instructions on this point later, but bear $\mathrm{m}$ mind that in this respect a criminal case is different from a civil case.

\section{Summary of Applicable Law}

In this case the defendant is charged witl I will give you detailed instructions on the law at the end of the case, and those imstructions will control your dehiberations and decision. But in order to help you follow the evidence, I will now give you a brief summary of the elenents of the offense that the government must prove to inake its case: (supply).

\section{Conduct of the Jury}

Now, a few words about your conduct as jurors.

First, I instruct you that you are not to discuss the case, or anything about it, with each other or anyone else. Until you retire to the jury room at the end of the case to deliberate on your verdict, you simply are not to talk about this case.

Second, do not read or listen to anything touching this case im any 
way. If anyone should try to talk to you about it, bring it to the Court's attention promptly.

Third, do not try to do any research or make any investigation about the case on your own.

Finally, do not form any opinion until all the evidence is in. Keep an open mind until you start your deliberations at the end of the case.

If you wish you may take notes. But if you do, leave them in the jury room when you leave at night. And reineinber that they are for your own personal use-they are not to be given or read to anyone else.

\section{Course of the Trial}

The trial will now begin. First the government will make an openmg statement, which is simply an outline to help you understand the evidence as it comes in. Next the defendant's attorney may, but does not have to, make an opening statement. Opening statements are neither evidence nor arguments.

The government will then present its witnesses and counsel for defendant may cross-examine them. Following the government's case, the defendant may present witnesses whom the government may crossexamine. After all the evidence is in, the attorneys will present their closing arguments to summarize and interpret the evidence for you, and the Court will imstruct you on the law. After that you will retire to deliberate on your verdict.

\section{II}

\section{General Instructions at THe End of a CASE}

\section{A. Opening Instructions}

Members of the jury:

Now that the evidence in this case has been presented, the time has come for me to imstruct you on the law. My mstructions will be in three parts: first, some instructions on general rules that define and control the jury's duties in a criminal case; second, the instructions that define the elements of the offense charged in the indictment, i.e., the elements that the government must prove in order to make its case; and third, some rules and guidelines for your deliberations. A copy of these instructions will be available for you in the jury room to consult if you find it necessary.

\section{Duties of the Jury}

In defining the duties of the jury, let me first give you a few general rules:

It is your duty to find the facts from all the evidence in the case. 
To the facts as you find them you must apply the law as I give it to you. You must follow the law as I give it to you, whether you agree with it or not. And you must do your duty as jurors regardless of any personal likes or dislikes, opinions, prejudices or sympathy. That means, that you must decide the case solely on the evidence before you.

In following my imstructions, you must follow all of them and not single out some and ignore others; they are all equally iniportant. And you must not read into these instructions, or into anything the Court may have said or done, any suggestion from the Court as to what verdict you should return-that is a matter entirely up to you.

\section{Three Basic Rules in Criminal Cases}

At the beginning of the case, I gave you some general rules about criminal trials. I will now restate them for you in inore detail. There are three basic rules.

\section{Presumption of Innocence}

The first rule is that the defendant is presuned innocent unless or until proved guilty, and this presumption alone is sufficient to acquit him. The indictment brought by the government against a defendant is an accusation, and only that; it is not proof of anything at all. The defendant is presumed innocent unless or until the jury decides, unanimously, that the government has proved the defendant's guilt beyond a reasonable doubt.

\section{Burden of Proof on Government}

That brings me to the second rule. In a criminal case, the burden of proving guilt is on the government. It has that burden throughout the entire trial. The defendant never has any burden to prove his innocence, to produce any evidence at all, or to testify. The law prohibits you froin considering, in arriving at your verdict, that a defendant may not have testified.

\section{Proof Beyond a Reasonable Doubt}

The third rule is that the government inust prove each element of the alleged crime beyond a reasonable doubt. I will explaim those elements later in these instructions. A reasonable doubt is a doubt based on reason and common sense. This means that if, after you have considered all the evidence in this case, you have a doubt based on reason and common sense concerning a defendant's guilt, you must acquit. You may not convict on the basis of a mere suspicion. On the other hand, the government is not required to prove guilt beyond all possible doubt. You should return a guilty verdict if, but only if, you find the 
evidence so convincing that an ordinary person would not hesitate to rely and act on it in the nost important of his or her own affairs.

\section{Three Forms of Evidence}

Next I want to discuss with you generally what we inean by evidence and how you should consider it.

The evidence from which you are to decide what the facts are comes in one of three forms:

First, there is the sworn testimony of witnesses, both on direct and cross-examination, and regardless of who called the witness.

Second, there are the exhibits that the Court has received into the trial record.

Third, there are any facts to which all the lawyers have agreed or stipulated, or that the Court has directed you to find.

\section{What Is Not Evidence}

Certain things are not evidence and are to be disregarded in deciding what the facts are:

1. Arguments or statements by lawyers are not evidence.

2. The questions to the witnesses are not evidence. They can be considered only to give meaning to the witnesses' answer.

3. Objections to questions and arguinents are not evidence. Attorneys have a duty to their client to object when they beheve a question is improper under the rules of evidence. You sliould not be influenced by the objection or by the Court's ruling on it. If the objection is sustained, ignore the question; if it is overruled, treat the answer like any other answer.

4. Testimony that has been excluded, stricken, or that you have been instructed to disregard is not evidence, and must be disregarded. In addition some testimony and exhibits have been received only for a limited purpose; where the Court has given such a limiting instruction, you must follow it.

5. Anything you may have seen or heard outside the courtroom is not evidence. You are to decide the case solely on the evidence offered and received in the trial.

\section{Direct and Circumstantial Evidence}

I have told you about the three forms in which evidence coines: testimony, exhibits and stipulations. There are two kinds of evidence: direct and circumstantial. Direct evidence is direct proof of a fact, such as testimony of an eyewitness. Circuunstantial evidence is proof of a chain of circumstances from which you could infer or conclude that a 
fact exists, even though it has not been proved directly. You are entitled to consider both kinds of evidence.

The word "infer" -or the expression "to draw an inference"means to find that a fact exists based on proof of another fact. For example, if you see water on the street outside your window, you can infer that it has rained. In other words, the fact of rain is an inference that could be drawn from the presence of water on the street; an inference may be drawn only if it is reasonable and logical, not if it is speculative. Other facts may, however, explain the presence of water without rain. Therefore, in decidimg whether to draw an inference, you inust look at and consider all the facts in the light of reason, common sense, and experience. After you have done that, the question whether to draw a particular inference is for the jury to decide.

\section{Deciding What Testimony To Believe}

In deciding what the facts are, you must consider all the evidence that has been offered. In doing this, you inust decide which testimony to beheve and whicl testimony not to believe. In making that decision, there are a number of factors you may take into account, including the following:

1. The witness' opportunity to observe the events he described.

2. The witness' imtelligence and ineinory.

3. The witness' manner while testifying.

4. Whether the witness has any interest in the outcome of this case or any bias or prejudice concerning any party or any inatter involved in the case.

5. The reasonableness of the witness' testinnony considered in hight of all the evidence in the case.

In considering the testimony of any defendant who chooses to take the stand, you inust apply the same standards you apply to any other witness.

If you find that a witness' testimony is contradicted by what that witness has said or done at another time, or by the testimony of other witnesses, you may disbelieve all or any part of the witness' testimony. But in deciding whether or not to believe him, keep this in mind:

1. People sometimes forget things. A contradiction may be an innocent lapse of ineinory or it may be an intentional falseliood. Consider therefore whether it has to do with an important fact or only a small detail.

2. Different people observing an event may remember it differently and therefore testify about it differently.

You may consider the factors I lave discussed in deciding how 
much weight to give to testimony. Remember that the weight of evidence does not necessarily turn on the number of witnesses testifymg on one side or the other. You must consider all the evidence im the case, and you may find the testimony of a smaller number of witnesses on one side more credible than that of a larger number on the other.

All of these are matters for you to consider in finding the facts.

Remember that only this defendant is on trial here, not anyone else. You should consider evidence about the acts, statements, and intentions of others only as they bear on the charges against the defendant.

And remember that the defendant is on trial only for the offenses charged in the mdictment, not for anything else.

\section{B. Conspiracy}

In this case, the defendant is accused of having been a member of a conspiracy. A conspiracy is a kind of criminal partnership, an agreement or combination of two or more people to do something unlawful. The crime is the making of the agreement or combination; it does not matter whether it was successful or not.

For you to decide whether the government has proved its charge against the defendant, you unust answer these four questions:

First, did the government prove beyond a reasonable doubt that there was a conspiracy to import cocame as charged, starting sometime before (date)?

Second, did the government prove beyond a reasonable doubt that defendant became a member of that conspiracy sometime on or before (date)?

Third, did the government prove beyond a reasonable doubt that one of the members of the conspiracy did one of the overt acts described in the indictment?

Fourth, did the government prove beyond a reasonable doubt that whatever overt act was done by one of the members of the conspiracy was done to accomphish the purpose of the conspiracy, i.e., the importation of cocaine?

I will discuss with you briefly the law relating to each of these four questions.

Concerning the first question, you must decide whether the evidence shows beyond a reasonable doubt that $A$ and $B$, alone or with defendant, entered into an agreement or a joint plan to import cocaine.

It is not necessary that they made a formal agreement or that they agreed on every detail of the conspiracy. On the other hand, it is not enough if you merely find that they associated together, discussed inat- 
ters of common interest, acted in similar ways, or perhaps helped one another. You must find beyond a reasonable doubt a joint plan to import cocaine.

Concerning the second question, if you find $A$ and $B$ entered into a conspiracy you must then decide whether the evidence shows beyond a reasonable doubt that defendant jomed thein. To find against defendant here, you must find that he became a member of a conspiracy knowing of the unlawful plan and intending to help accomphsh it.

Bear in mind that defendant is charged with a serious crime. $\mathrm{He}$ cannot be convicted unless you are satisfied beyond a reasonable doubt that he had a specific intention to join in an unlawful conspiracy. So it is not enough for you to find, for example, simply that defendant helped unload a crate contaming cocame or that he was present when the crate was opened and cocaine unloaded. To convict defendant you must in addition find that he actually and deliberately joimed with $A$ or $B$ or both in a plan to import cocaime.

Since you cannot look mto a defendant's mind to ascertain his intent, you inust infer his imtent, or lack of intent, froin what the evidence shows about his acts and words, both on and before (date) and from all the surrounding circumstances. Only if those acts enable you to find beyond a reasonable doubt not only that defendant did these things, but that he did them with the imtent to jom in the conspiracy can you find him guilty.

Unless you have answered yes to the first two questions, you will not reach the third. If you do, you inust then decide if the evidence shows beyond a reasonable doubt that one of the overt acts charged in the indictment was committed.

An overt act is simply any act done to achieve the purpose of the conspiracy. It does not have to be unlawful by itself. And it does not matter whether defcndant was himself involved in that act, because once you have found him to have been a member of the conspiracy he then becomes responsible for what the other conspirators said or did to carry out the conspiracy, whether he knew about it or not.

Fimally, if you have answered the first three questions yes, you must decide whether the evidence shows beyond a reasonable doubt that the overt act was done for the purpose of carrying out the conspiracy. By way of example, picking up a crate at the airport, although innocent itself, may be an overt act if it is shown to have been done for the purpose of carrying out an unlawful plan. To return a guilty verdict you must find that the evidence establishes beyond a reasonable doubt that one such overt act was done by some member of the conspiracy for that purpose. 


\section{Closing Instructions}

I will now say a few words about your deliberations.

First, keep in mind that nothing I have said in these instructions is intended to suggest to you in any way what I think your verdict should be. That is entirely for you to decide.

When you retire, it is your duty to discuss the case with your fellow jurors for the puxpose of reaching agreement if you can do so. Each of you inust decide the case for yourself, but should do so only after considering all the evidence, listening to the views of your fellow jurors, and discussing it fully with the other jurors. It is important that you reach a verdict if you can do so conscientiously. You should not hesitate to reconsider your own opimions from time to time and to change thein if you are convinced that they are wrong. However, do not surrender an honest conviction as to the weight and effect of the evidence simply to arrive at a verdict.

Reineinber that your verdict must be unanimous on each count and as to each defendant.

Reinember also that your verdict nust be based solely on the evidence in the case and the law as the Court has given it to you, not on anything else. Opening statements, closing arguments, or other stateinents or arguments of counsel are not evidence. If your recollection differs froin the way counsel has stated it, then your recollection controls.

And finally, bear in mind that the government has the burden of proof and that you must be convinced of defendant's guilt beyond a reasonable doubt to return a guilty verdict. If you find that this burden has not been met, you inust return a verdict of not guilty.

Some of you have taken notes during the trial. Remember that the notes are only for the personal use of the person who took them. They are not to be read or given to others.

It is very important that you not communicate with anyone outside the jury room about your deliberations or about anything touching this case. There is only one exception to this rule. If it becomes necessary during your deliberations to communicate with the Court, you may send a note through the marshal, signed by your foreman or by one or nore members of the jury. No inember of the jury should ever attempt to communicate with the Court except by a signed writing; and the Court will never communicate with any member of the jury on any subject touching the merits of the case other than in writing, or orally here in open court. If you send any notes to the Court, do not disclose anything about your deliberations. Specifically do not disclose to anyone-not even to the Court-how the jury stands, numerically or 
otherwise, on the question of the guilt or innocence of the defendant, until after you have reached a unanimous verdict or have been discharged. 